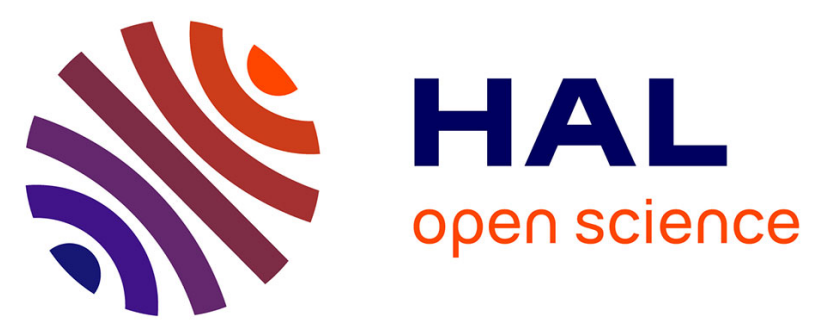

\title{
Conformationally dynamic titanium and zirconium cationic complexes of bis(naphthoxy)pyridine ligands: structure, "oscillation" and olefin polymerization catalysis
}

Liana Annunziata, Thierry Roisnel, Abbas Razavi, Jean-François Carpentier, Evgueni Kirillov

\section{To cite this version:}

Liana Annunziata, Thierry Roisnel, Abbas Razavi, Jean-François Carpentier, Evgueni Kirillov. Conformationally dynamic titanium and zirconium cationic complexes of bis(naphthoxy)pyridine ligands: structure, "oscillation" and olefin polymerization catalysis. Dalton Transactions, 2017, 46 (10), pp.3150-3159. 10.1039/c6dt04680k . hal-01501258

\section{HAL Id: hal-01501258}

\author{
https://hal-univ-rennes1.archives-ouvertes.fr/hal-01501258
}

Submitted on 10 Jul 2017

HAL is a multi-disciplinary open access archive for the deposit and dissemination of scientific research documents, whether they are published or not. The documents may come from teaching and research institutions in France or abroad, or from public or private research centers.
L'archive ouverte pluridisciplinaire HAL, est destinée au dépôt et à la diffusion de documents scientifiques de niveau recherche, publiés ou non, émanant des établissements d'enseignement et de recherche français ou étrangers, des laboratoires publics ou privés. 
For the Table of Contents entry

Conformationally Dynamic Titanium and Zirconium Cationic Complexes of Bis(naphthoxy)pyridine ligands: Structure, “Oscillation” and Olefin Polymerization Catalysis

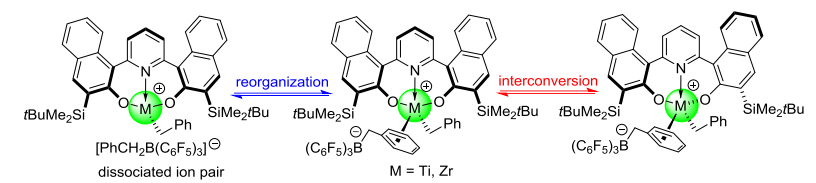

The interconversion and reorganization processes occurring in cationic $\mathrm{Ti}$ and $\mathrm{Zr}$ complexes were studied by NMR techniques and DFT computations. 


\title{
Conformationally Dynamic Titanium and Zirconium Cationic Complexes of
}

\section{Bis(naphthoxy)pyridine ligands: Structure, "Oscillation" and Olefin Polymerization Catalysis}

\author{
Liana Annunziata, ${ }^{\dagger}$ Thierry Roisnel, ${ }^{\dagger}$ Abbas Razavi, ${ }^{*}$ Jean-François Carpentier ${ }^{\dagger}, *$ and Evgueni \\ Kirillov, ${ }^{\dagger}, *$
}

+Université de Rennes 1, CNRS, Institut des Sciences Chimiques de Rennes, UMR 6226, F35042 Rennes Cedex, France

\# Total Petrochemicals Research, Zone Industrielle C, B-7181 Feluy, Belgium

\begin{abstract}
Discrete ionic complexes $\left\{\mathrm{ONO}^{\mathrm{SiMe} 2 t \mathrm{Bu}}\right\} \mathrm{M}\left(\mathrm{CH}_{2} \mathrm{Ph}\right)\left(\left(\eta^{6}-\mathrm{Ph}\right) \mathrm{CH}_{2} \mathrm{~B}\left(\mathrm{C}_{6} \mathrm{~F}_{5}\right)_{3}\right)(\mathrm{M}=\mathrm{Ti}, \mathbf{2}-\mathbf{T i}$; $\mathrm{Zr}, \mathbf{2 - Z r})$ have been prepared from the parent neutral dibenzyl precursors and $\mathrm{B}\left(\mathrm{C}_{6} \mathrm{~F}_{5}\right)_{3}$. Also, a neutral dichloro complex $\left\{\mathrm{ONO}^{\mathrm{SiMe} 2 t \mathrm{Bu}}\right\} \mathrm{ZrCl}_{2}\left(\mathrm{Me}_{2} \mathrm{NH}\right)$ (3) was synthesized by reaction of proligand $\left\{\mathrm{ONO}^{\mathrm{SiMe} 2 t \mathrm{Bu}}\right\} \mathrm{H}_{2}\left(\mathbf{1}-\mathrm{H}_{2}\right)$ with $\left(\mathrm{Me}_{2} \mathrm{~N}\right)_{2} \mathrm{ZrCl}_{2}(\mathrm{DME})$. The compounds were characterized

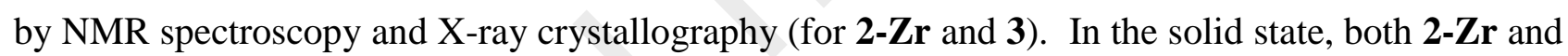

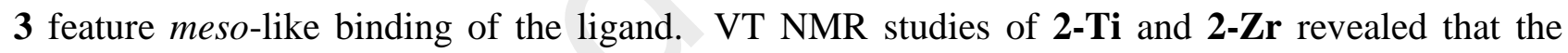
former species dissociates in solution to form an outer-sphere ion pair (OSIP) that features a complicated dynamic behavior, while the latter compound retains an inner-sphere ion pair (ISIP) structure that interconverts between $C_{\mathrm{s}}$-symmetric (meso-like) and $C_{1}$-symmetric (rac-like) conformations. The mechanism of this interconversion was assessed by DFT calculations and the corresponding barrier for the straightforward interconversion was calculated $\left(\Delta E^{f} C_{s} \leftrightarrow C 1=13.8\right.$ $\left.\mathrm{kcal} \cdot \mathrm{mol}^{-1}\right)$.
\end{abstract}

\footnotetext{
*Corresponding authors: Fax: (+33)(0)223-236-939. E-mail: jean-francois.carpentier@univrennes1.fr; $\underline{\text { evgueni.kirillov@univ-rennes1.fr. }}$
} 


\section{Introduction}

Geometrically conformable ("oscillating") polymerization catalysts, which exhibit a dynamic interconversion between several geometrically stable isomers, are of fundamental interest as unique systems granting access to controlled synthesis of stereoblock polyolefins using single monomer feed. ${ }^{1}$ Pioneering studies by Waymouth ${ }^{2}$ and others ${ }^{3}$ on the atropisomeric metallocenium cations $\left[(2-\mathrm{Ph}-(\mathrm{R}-\mathrm{Ind}))_{2} \mathrm{ZrMe}\right]^{+}$indicated that those species presumably exist under $\mathrm{rac}$ and meso conformational states in a "quasi-controlled" equilibrium; yet, further studies by Busico et $a l .{ }^{4}$ and others $^{5}$ revealed a more complicated nature of such interconversion in metallocene catalysts. More recently, several post-metallocene systems were designed with the aim to gain a better control over the "oscillation" process. For example, geometrically conformable complexes of group 4 metals incorporating different pincer $\mathrm{LX}_{2}$-type ligands were scrutinized by Bercaw et al. ${ }^{6}$ in polymerization of propylene and shown to produce atactic polymers due to a fast exchange between species of different symmetry.

In a previous contribution, we have reported neutral group 4 metal (Ti, Zr, Hf) complexes of sterically demanding silyl ortho-substituted tridentate 2,6-bis(naphthoxy)pyridine $\left(\left\{\mathrm{ONO}^{\mathrm{SiR} 3}\right\}^{2-}\right.$, $\left.\mathrm{SiR}_{3}=\mathrm{SiPh}_{3}, \mathrm{SiMe}_{2} t \mathrm{Bu}\right)$ and 2,5-bis(naphthoxy)thiophene $\left(\left\{\mathrm{OSO}^{\mathrm{SiPh} 3}\right\}^{2-}\right)$ ligands. $^{7}$ In particular, we have shown that coordination of the $\left\{\mathrm{ONO}^{\mathrm{SiR} 3}\right\}^{2-}$ ligands onto the metal center gives rise to conformationally stable complexes existing either as rac-like or meso-like stereoisomers, whose structures were established both in the solid state and in solution. These stereoisomers featuring either $C_{2}$ - or $C_{\mathrm{s}^{-}}$-symmetry, respectively, interconvert relatively easily in solution (Scheme 1) with the following activation parameters: $\Delta H^{\ddagger}=12.9(7)-13.4(8) \mathrm{kcal} \cdot \mathrm{mol}^{-1}$ and $\Delta S^{\neq}=-3(1)--7(1)$ $\mathrm{cal} \cdot \mathrm{mol}^{-1} \cdot \mathrm{K}^{-1}$. 


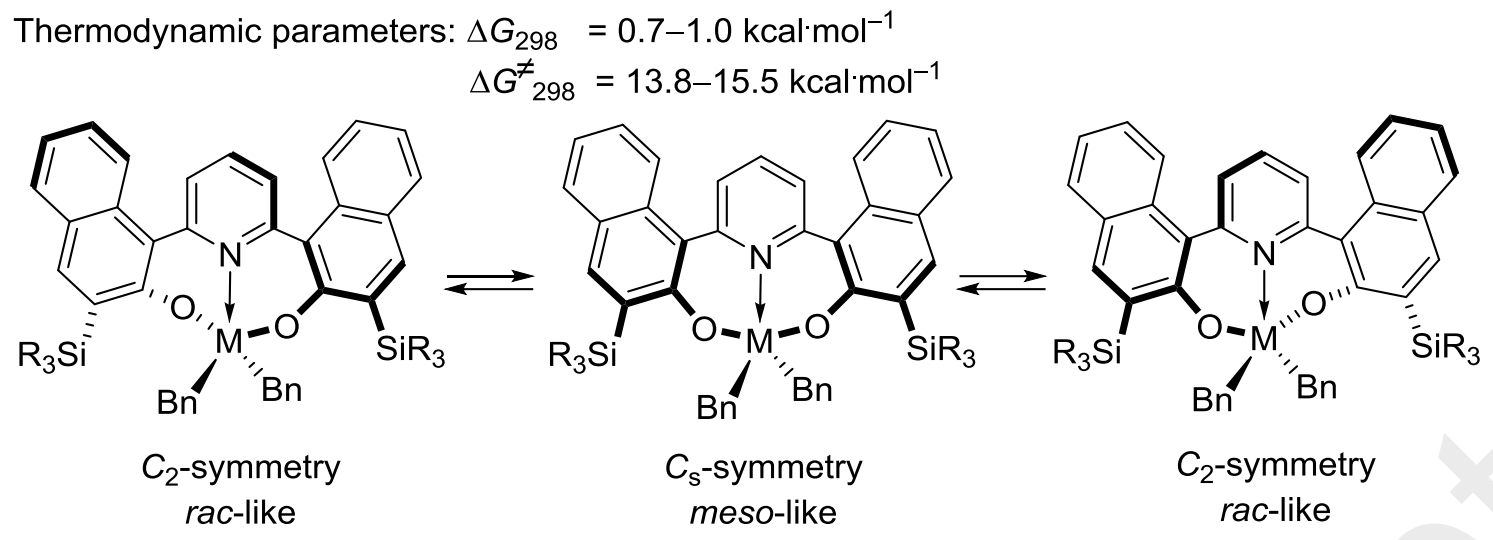

Scheme 1. Reversible interconversion between rac-like and meso-like geometries for neutral group 4 metal $(\mathrm{M}=\mathrm{Ti}, \mathrm{Zr}, \mathrm{Hf})$ complexes of the type $\{\mathrm{ONO}\} \mathrm{MBn}_{2}$.

Considering that these interconversion barriers are, in principle, slightly larger than those for propylene insertion $\left(\Delta G^{\neq}{ }_{173}=11.5(2) \mathrm{kcal} \cdot \mathrm{mol}^{-1}\right.$ for $\left(\mathrm{C}_{5} \mathrm{Me}_{5}\right)_{2} \mathrm{YCH}_{2} \mathrm{CH}_{2} \mathrm{CH}(\mathrm{Me})_{2}$, as determined by NMR spectroscopy), ${ }^{8,9}$ the titled $\{\mathrm{ONO}\} \mathrm{MBn}_{2}$ systems may have been anticipated to produce polymers incorporating relatively long stereoblocks. However, only low molecular weight polypropylenes with a regioirregular, atactic microstructure were systematically obtained instead. ${ }^{7}$

In this contribution, we report on the synthesis of titanium and zirconium ion-pairs from the reaction of neutral complexes $\left\{\mathrm{ONO}^{\mathrm{SiMe} 2 t \mathrm{Bu}}\right\} \mathrm{Ti}\left(\mathrm{CH}_{2} \mathrm{Ph}\right)_{2}(\mathbf{1 - T i})$ and $\left\{\mathrm{ONO}^{\mathrm{SiMe} 2 t \mathrm{Bu}}\right\} \mathrm{Zr}\left(\mathrm{CH}_{2} \mathrm{Ph}\right)_{2}(\mathbf{1 -}$ Zr) with $\mathrm{B}\left(\mathrm{C}_{6} \mathrm{~F}_{5}\right)_{3}{ }^{10}$ The solution and solid-state structures and the interconversion/reorganization processes have been investigated by experimental (X-ray crystallography, NMR spectroscopy) and DFT methods. Also, the catalytic performance of these cationic systems has been preliminarily explored in propylene and styrene polymerization reactions (see the SI).

\section{Results and Discussion}

Generation of ion-pairs $\left\{\mathrm{ONO}^{\mathrm{SiMe} 2 t \mathrm{Bu}}\right\} \mathrm{M}\left(\mathrm{CH}_{2} \mathrm{Ph}\right)\left(\left(\eta^{6}-\mathrm{Ph}\right) \mathrm{CH}_{2} \mathrm{~B}\left(\mathrm{C}_{6} \mathrm{~F}_{5}\right) 3\right)(\mathrm{M}=\mathrm{Ti}, \mathrm{Zr})$. Treatment of 1-Ti and 1-Zr with one equiv of $\mathrm{B}\left(\mathrm{C}_{6} \mathrm{~F}_{5}\right)_{3},{ }^{11}$ carried out on a NMR scale in toluene- $d_{8}$ in the $-50-+25{ }^{\circ} \mathrm{C}$ temperature range, resulted in complete and clean generation of the 
corresponding ion-pairs 2-Ti and 2-Zr (Scheme 2), respectively. Both compounds were prepared on a larger scale and isolated as yellow-orange and brown-orange solids, respectively. The identity of these two compounds was established by elemental analysis, ${ }^{1} \mathrm{H},{ }^{11} \mathrm{~B},{ }^{19} \mathrm{~F}$ and ${ }^{13} \mathrm{C}$ NMR spectroscopic studies in solution, and single-crystal X-ray diffraction studies for $\mathbf{2}-\mathbf{Z r}$.

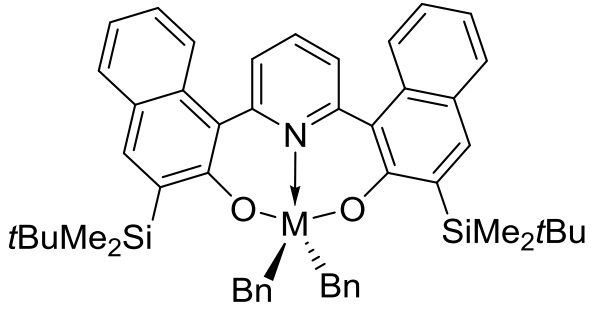

1-Ti: $\left\{\mathrm{ONO}^{\mathrm{SiMe} 2 t \mathrm{Bu}}\right\} \mathrm{Ti}\left(\mathrm{CH}_{2} \mathrm{Ph}\right)_{2}$

1-Zr: $\left\{\mathrm{ONO}^{\mathrm{SiMe} 2 \mathrm{BBu}}\right\} \mathrm{Zr}\left(\mathrm{CH}_{2} \mathrm{Ph}\right)_{2}$

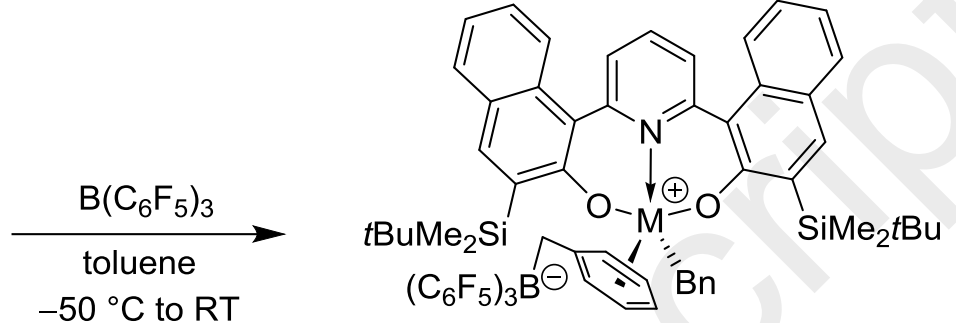

2-Ti: $\left\{\mathrm{ONO}^{\mathrm{SiMe} 2 t \mathrm{Bu}}\right\} \mathrm{Ti}\left(\mathrm{CH}_{2} \mathrm{Ph}\right)\left(\left(\eta^{6}-\mathrm{Ph}\right) \mathrm{CH}_{2} \mathrm{~B}\left(\mathrm{C}_{6} \mathrm{~F}_{5}\right)_{3}\right)$

2-Zr: $\left\{\mathrm{ONO}^{\mathrm{SiMe} 2 \mathrm{Bu}}\right\} \mathrm{Zr}\left(\mathrm{CH}_{2} \mathrm{Ph}\right)\left(\left(\eta^{6}-\mathrm{Ph}\right) \mathrm{CH}_{2} \mathrm{~B}\left(\mathrm{C}_{6} \mathrm{~F}_{5}\right)_{3}\right)$

Scheme 2. Generation of ion-pairs 2-Ti and $\mathbf{2 - Z r}$ by reactions of dibenzyl complexes 1-Ti and $\mathbf{1 - Z r}$ with $\mathrm{B}\left(\mathrm{C}_{6} \mathrm{~F}_{5}\right)_{3}$.

Single crystals of $\mathbf{2 - Z \mathbf { r }}$ suitable for X-ray diffraction studies were prepared by recrystallization of the crude material from toluene. In the solid state (Fig. 1), the organization of 2$\mathbf{Z r}$ is the same as that of other related inner sphere ion-pairs (ISIP) incorporating $\left[\mathrm{BnB}\left(\mathrm{C}_{6} \mathrm{~F}_{5}\right)_{3}\right]^{-}$ counteranion. ${ }^{10 \mathrm{a}-\mathrm{h}}$ Thus, the molecule consists of the $\left[\left\{\mathrm{ONO}^{\mathrm{SiMe} 2 t \mathrm{Bu}}\right\} \mathrm{Zr}\left(\eta^{2}-\mathrm{CH}_{2} \mathrm{Ph}\right)\right]^{+}$cation $\pi-$ bound to the aromatic ring of the benzyl group of $\left[\mathrm{BnB}\left(\mathrm{C}_{6} \mathrm{~F}_{5}\right)_{3}\right]^{-}$. The five $\mathrm{Zr}(1)-\mathrm{C}($ arene $)$ distances between the cationic metal center and the aromatic ring are very close to each other (2.743(2)2.765(2) $\AA$ ), while the $\operatorname{Zr}(1)-C_{\text {ipso }}(\operatorname{Zr}(1)-C(21))$, is somewhat longer $(2.813(2) \AA)$. These bond lengths as well as the $\mathrm{Zr}(1)-\mathrm{Ph}_{\text {cent }}$ one $(2.384(2) \AA)$ are in the normal range of values $(2.555-2.860$ and 2.300-2.385 $\AA$, respectively) observed for similar zirconium associated ion-pairs. ${ }^{10 \mathrm{a}-\mathrm{h}} \eta^{2}$ Binding of the benzyl ligand with the metal center is evidenced from the short $\operatorname{Zr}(1)-\mathrm{C}(1)_{i p s o}$ bond (2.682(2) $\AA$ ) and acute $\mathrm{Zr}(1)-\mathrm{C}(1)-\mathrm{C}(1)_{\text {ipso }}$ angle $\left(90.50(8)^{\circ}\right)$, both values being very close to those observed in the parent neutral 1-Zr $\left(2.632(6) \AA \text { and } 89.55(2)^{\circ} \text {, respectively }\right)^{7}$ featuring the same 
mode of coordination. The 2,6-bis(naphthoxy)pyridine ligand in $\mathbf{2 - Z \mathbf { r }}$ is also coordinated in a $C_{\mathrm{s}^{-}}$ symmetric fashion akin for the parent neutral $\mathbf{1 - Z r}$, thus exhibiting close twist angles between the planes of the pyridine and naphtholate fragments (57.86 and $58.46^{\circ}$ vs. 50.96 and $62.68^{\circ}$, respectively). Also, the corresponding $\operatorname{Zr}(1)-\mathrm{O}$ and $\operatorname{Zr}(1)-\mathrm{N}$ bond distances in $2-\mathrm{Zr}$ (2.0023(16), 2.0028(16) and 2.4045(19) $\AA$, respectively) are very similar to those observed in $\mathbf{1 - Z r}(1.995(5)$, 2.018(5) and 2.449(6) ̊, respectively). ${ }^{7}$

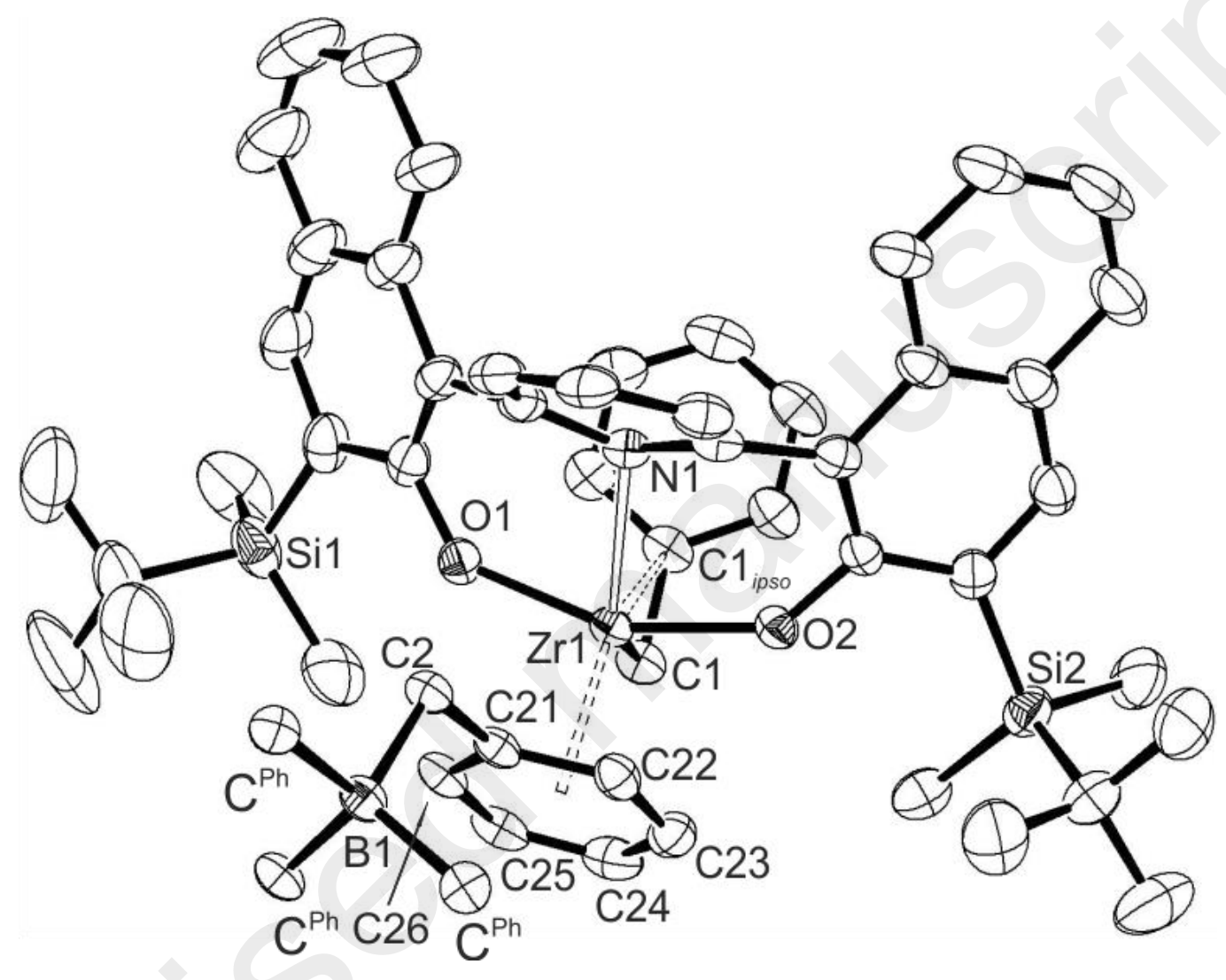

Figure 1. Molecular structure of $\left\{\mathrm{ONO}^{\mathrm{SiMe} 2 t \mathrm{Bu}}\right\} \mathrm{Zr}\left(\mathrm{CH}_{2} \mathrm{Ph}\right)\left(\left(\eta^{6}-\mathrm{Ph}\right) \mathrm{CH}_{2} \mathrm{~B}\left(\mathrm{C}_{6} \mathrm{~F}_{5}\right)_{3}\right)$ (2-Zr). (all hydrogen atoms and pentafluorophenyl groups are omitted for clarity; thermal ellipsoids drawn at the 50\% probability). Selected bond distances $(\AA)$ and angles $\left(^{\circ}\right): \operatorname{Zr}(1)-\mathrm{O}(1), 2.0023(16), \operatorname{Zr}(1)-$ $\mathrm{O}(2), 2.0028(16) ; \operatorname{Zr}(1)-\mathrm{N}(1), 2.4045(19) ; \operatorname{Zr}(1)-\mathrm{C}(1), 2.225(2) ; \operatorname{Zr}(1)-\mathrm{C}(1)_{i p s o}, 2.682(2) ; \operatorname{Zr}(1)-$ $\mathrm{Ph}_{\text {cent }}, 2.384(2) ; \operatorname{Zr}(1)-\mathrm{C}(21), 2.813(2) ; \operatorname{Zr}(1)-\mathrm{C}(22), 2.749(3) ; \operatorname{Zr}(1)-\mathrm{C}(23), 2.751(2) ; \operatorname{Zr}(1)-\mathrm{C}(24)$, 2.749(2); $\mathrm{Zr}(1)-\mathrm{C}(25), 2.743(2) ; \mathrm{Zr}(1)-\mathrm{C}(26), 2.765(2) ; \mathrm{B}(1)-\mathrm{C}(2), 1.678(3) ; \mathrm{O}(1)-\mathrm{Zr}(1)-\mathrm{O}(2)$, 156.71(7); $\quad \mathrm{N}(1)-\mathrm{Zr}(1)-\mathrm{C}(1), \quad 130.32(7) ; \quad \mathrm{Zr}(1)-\mathrm{C}(1)-\mathrm{C}(1)_{\text {ipso }}, \quad 90.50(8) ; \quad \mathrm{N}(1)-\mathrm{Zr}(1)-\mathrm{Ph}_{\text {cent }}$, 122.88(8). 
Solution Structure and Dynamic Properties of Cationic Complexes. For complex 2-Ti, resonances in the room-temperature ${ }^{1} \mathrm{H}$ and ${ }^{13} \mathrm{C}\left\{{ }^{1} \mathrm{H}\right\}$ NMR spectra in toluene- $d_{8}$ (Fig. S1 and S2, respectively) are all consistent with a single average symmetric structure on the NMR time scale. The difference in the chemical shifts of the meta- and para-F resonances $(|\Delta \delta(m, p-\mathrm{F})|)$ in the room-temperature ${ }^{19} \mathrm{~F}$ NMR spectrum of 2-Ti (Fig. S3) of 2.6 ppm suggests that this complex dissociates in solution converting to outer-sphere ion-pairs (OSIP). ${ }^{12}$

Upon cooling a toluene- $d_{8}$ solution of 2-Ti (Fig. S4), the signals in the ${ }^{1} \mathrm{H}$ NMR spectrum broadened and decoalesced $\left(T_{\text {coal }}=c a .-30{ }^{\circ} \mathrm{C}\right.$ for $\mathrm{H}^{4}$ at $\left.500 \mathrm{MHz}\right)$; however, subsequent gradual cooling to $-70{ }^{\circ} \mathrm{C}$ only resulted in significant broadening of all signals, thus, hampering their proper integration and interpretation of the global data. A clearer picture was obtained from the VT ${ }^{29} \mathrm{Si}\left\{{ }^{1} \mathrm{H}\right\}$ NMR studies (Fig. S5). The signal from the $\mathrm{SiMe} 2 \mathrm{Bu}$ groups decoalesced at $18{ }^{\circ} \mathrm{C}$ and split and sharpened giving rise to three sets of signals assigned to three species of different symmetry. Two of them (found in ca. 5:1 molar ratio), both of $C_{1}$-symmetry, are represented each in the ${ }^{29} \mathrm{Si}\left\{{ }^{1} \mathrm{H}\right\}$ NMR spectrum (Fig. S6) by two singlet resonances of equal intensity, while the third minor one apparently exhibits $C_{\mathrm{s}}$-symmetry as it displays only one singlet resonance shifted upfield for equivalent $\mathrm{SiMe} 2 \mathrm{tBu}$ groups. ${ }^{13}$ Upon raising the temperature up to $60{ }^{\circ} \mathrm{C}$, the resonances of 2-Ti in the ${ }^{1} \mathrm{H}$ NMR spectrum broadened again (Fig. S4), and other signals from unidentified species appeared. This may be indicative of possible degradation of this cationic complex upon heating.

Complex 2-Zr also adopts an average symmetric structure on the NMR time scale at room temperature in toluene- $d_{8}$, as judged from the corresponding ${ }^{1} \mathrm{H}$ and ${ }^{13} \mathrm{C}$ NMR data. For example, key resonances in the ${ }^{1} \mathrm{H}$ NMR spectrum include: (a) one broadened singlet for $\mathrm{H}^{4}$ hydrogens of the naphthoxy groups, ${ }^{14}$ (b) a series of three broadened multiplets for the aromatic hydrogens of one benzyl group, (c) two broadened resonances for the two $\mathrm{CH}_{2}$ benzyl groups, (d) a single resonance for the two $t \mathrm{Bu}$ groups, (e) two singlets for the four diastereotopic SiMeMe groups. In contrast with

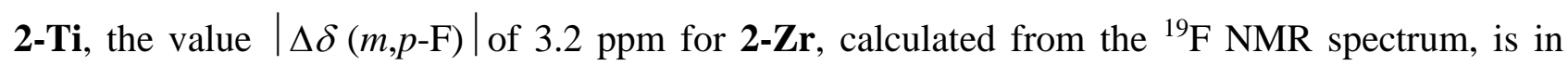


agreement with the ISIP nature of this species. ${ }^{12}$ Upon cooling a toluene solution of $2-Z \mathbf{r}$ (Fig. S8), the signals in the ${ }^{1} \mathrm{H}$ NMR spectrum decoalesced $\left(T_{\text {coal }}=c a .-30{ }^{\circ} \mathrm{C}\right)$ and, finally, split and sharpened at $-50{ }^{\circ} \mathrm{C}$. At this temperature, the ${ }^{1} \mathrm{H}$ NMR spectrum of $\mathbf{2 - Z \mathbf { r }}$ features two sets of signals assigned to two species in a $c a$. 1.2:1 molar ratio (Fig. 2). The predominant compound is represented by two singlets at $\delta 8.19$ and $7.87 \mathrm{ppm}$ for the naphthoxy $\mathrm{H}^{4}$ hydrogens, two broad multiplets at $\delta 3.69$ and $3.60 \mathrm{ppm}$ for diastereotopic $\mathrm{BCH} H \mathrm{Ph}$ hydrogens, two doublets at $\delta 3.08$ and $2.96 \mathrm{ppm}\left({ }^{2} J_{\mathrm{H}-\mathrm{H}}=10.1 \mathrm{~Hz}\right)$ characteristic of an $\mathrm{AB}$ system for diastereotopic $\mathrm{ZrCH} H \mathrm{Ph}$ hydrogens, two singlet resonances at $\delta 1.07$ and $0.93 \mathrm{ppm}$ for the $t \mathrm{Bu}$ groups, and four singlets at $\delta$ 0.63, 0.60, 0.59 and $0.52 \mathrm{ppm}$ for non-equivalent SiMeMe groups. Most of the resonances of the second compound overlap with those of the major compound; however, some key resonances were identified: the resonance for the naphthoxy $\mathrm{H}^{4}$ hydrogens is found at $\delta 8.12 \mathrm{ppm}$, two very broad signals for the $\mathrm{B}\left(\mathrm{CH}_{2} \mathrm{Ph}\right)$ and $\mathrm{Zr}\left(\mathrm{CH}_{2} \mathrm{Ph}\right)$ groups appear at $\delta 3.26$ and 2.50 ppm, while resonances for the $t \mathrm{Bu}$ and non-equivalent $\mathrm{SiMeMe}$ groups are found at $\delta 1.09 \mathrm{ppm}$ and $\delta 0.69$ and $0.49 \mathrm{ppm}$, respectively. As evidenced from the $\mathrm{VT}{ }^{29} \mathrm{Si}\left\{{ }^{1} \mathrm{H}\right\}$ NMR study (Fig. S12), the spectrum splits into two series of signals at $-50{ }^{\circ} \mathrm{C}$ : two resonances of equal intensity at $\delta 4.5$ and $3.4 \mathrm{ppm}$, and a single signal at $\delta 3.5 \mathrm{ppm}$. Also, in the ${ }^{11} \mathrm{~B}\left\{{ }^{1} \mathrm{H}\right\}$ NMR spectrum recorded at the same temperature, the two species afforded two resonances at $\delta-11.8$ and $-12.2 \mathrm{ppm}$. Finally, the differences in the chemical shifts $(|\Delta \delta(m, p-\mathrm{F})|)$ determined at $-50{ }^{\circ} \mathrm{C}$ for the two isomers of $\mathbf{2 - Z} \mathbf{Z r}$ of 3.5 and $4.0 \mathrm{ppm}$ are in agreement with ISIP structures in solution. Further cooling a solution of $\mathbf{2 - Z r}$ at $-70{ }^{\circ} \mathbf{C}$, resulted in broadening of all resonances due to the precipitation of compound. Overall, these observations are consistent with $\mathbf{2 - Z r}$ existing as a mixture of two isomers of different symmetry, namely, $C_{1}$ or rac2-Zr (major) and $C_{\mathrm{s}}$ or meso-2-Zr (minor; as observed in the solid state), which dynamically interconvert via an equilibrium, fast on the NMR time scale. At $-50{ }^{\circ} \mathrm{C}$, when the interconversion process is frozen, the molar ratio between these species ${ }^{15}$ allowed calculating the energy difference $\left(0.1 \mathrm{kcal} \cdot \mathrm{mol}^{-1}\right)$ between the two ground states using Maxwell-Boltzmann statistics. ${ }^{16}$ 


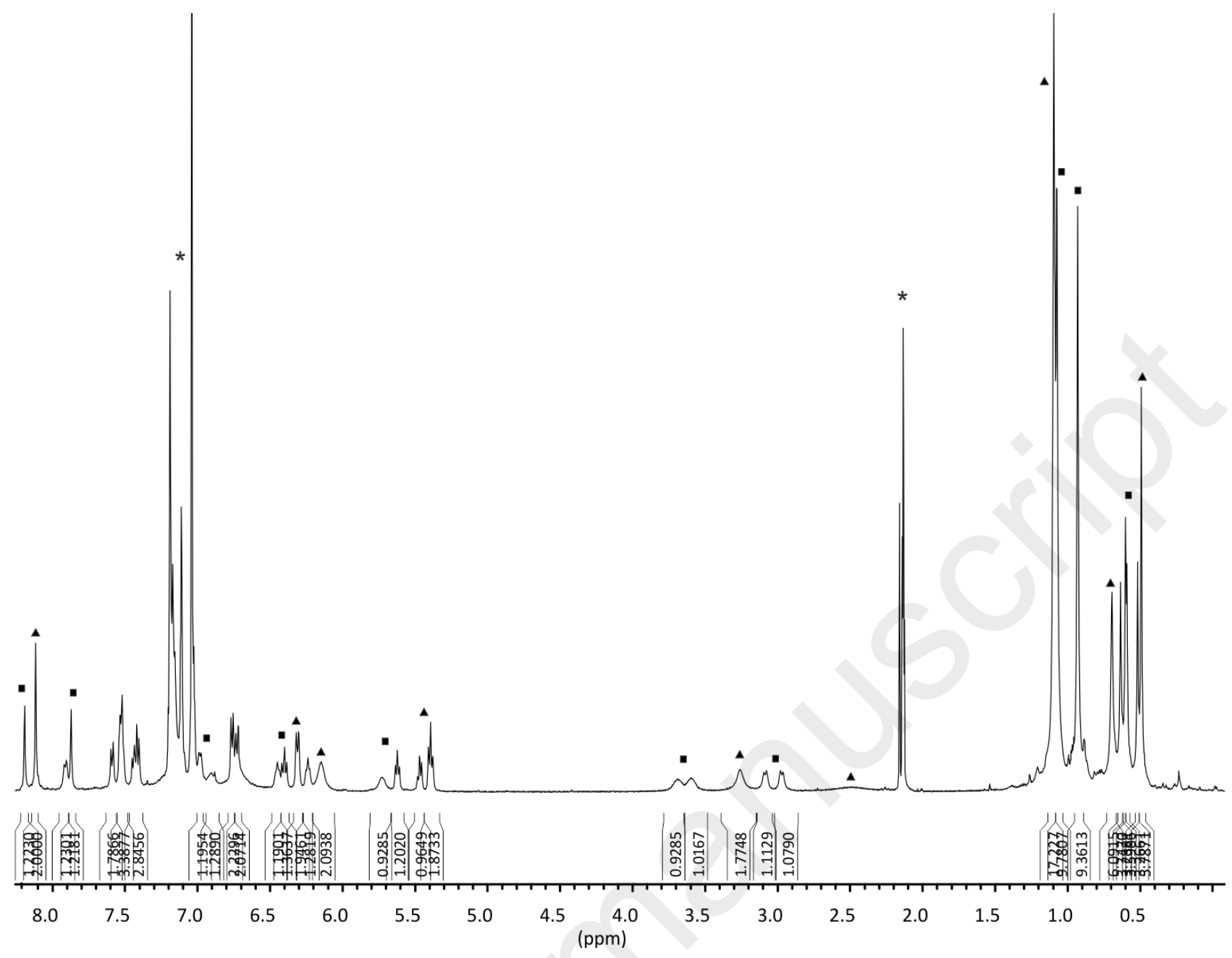

Figure 2. ${ }^{1} \mathrm{H}$ NMR $\left(500 \mathrm{MHz}\right.$, toluene- $\left.d_{8}, 223 \mathrm{~K}\right)$ spectrum of $\left\{\mathrm{ONO}^{\mathrm{SiMe} 2 t \mathrm{Bu}}\right\} \mathrm{Zr}\left(\mathrm{CH}_{2} \mathrm{Ph}\right)\left(\left(\eta^{6}-\right.\right.$ $\left.\mathrm{Ph}) \mathrm{CH}_{2} \mathrm{~B}\left(\mathrm{C}_{6} \mathrm{~F}_{5}\right)_{3}\right)(\mathbf{2 - Z r}) ; \boldsymbol{\square}=$ rac-2-Zr,, $\mathbf{\Delta}=$ meso-2-Zr $(*$ stands for residual solvent resonances $)$.

Theoretical investigation of the interconversion mechanism. To get a better insight on the possible nature of intermediates as well as the putative mechanism of interconversion that operates in these cationic group 4 metal bis(naphthoxy)pyridine systems, DFT calculations were carried out at the B3PW91 level (see the Experimental Section, Computational Details). Stationary points corresponding to the nine possible isomers for each ion-pairs of both $\mathrm{Ti}$ and $\mathrm{Zr}$ were optimized (Scheme 3): $C_{\mathrm{s}^{-}}$and $C_{1}$-symmetric ISIP 2-M- $C_{\mathrm{s}^{-}} \mathbf{u p}(\mathbf{1 , 2}), \mathbf{2}-\mathrm{M}-\boldsymbol{C}_{\mathrm{s}^{-}}-\operatorname{down}(\mathbf{1}, \mathbf{2})$ and 2-MC1-up, 2-M- $\boldsymbol{C}_{1}$-down featuring the up and down orientation of the bound $\left[\mathrm{BnB}\left(\mathrm{C}_{6} \mathrm{~F}_{5}\right)_{3}\right]^{-}$counterion, respectively, and $C_{\mathrm{s}^{-}}$and $C_{1}$-symmetric OSIP 2-M- $C_{\mathrm{s}}$-decoord(1,2) and 2-M- $C_{1}$-decoord. 


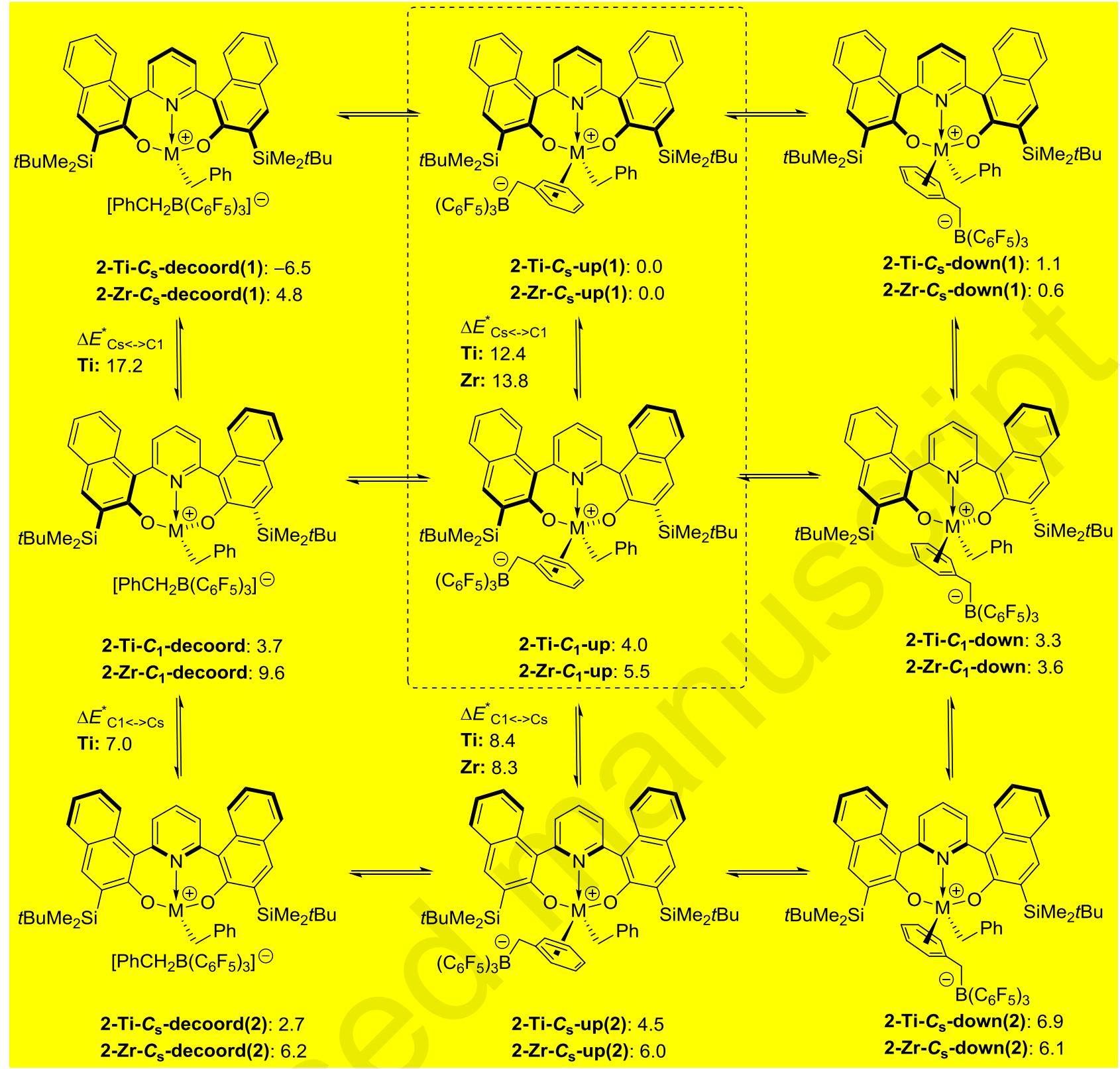

Scheme 3. The 9 optimized ISIP and OSIP isomers of cationic group 4 metal bis(naphthoxy)pyridine systems, and relative computed energies (in $\mathrm{kcal} \cdot \mathrm{mol}^{-1}$ ).

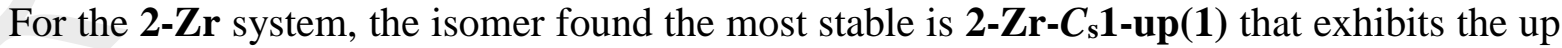
orientation of the $\pi$-Ph coordinated anion $\left[\mathrm{BnB}\left(\mathrm{C}_{6} \mathrm{~F}_{5}\right)_{3}\right]^{-}$, similar to that observed in the solid state by X-ray crystallography (Fig. 1). Its isomer of $C_{1}$-symmetry, $\mathbf{2}-\mathbf{Z r} \mathbf{r}-\boldsymbol{C}_{\mathbf{1}}$-up, available via the corresponding transition state $\left(\Delta E_{C s \leftrightarrow C 1}^{\neq}=13.8 \mathrm{kcal} \cdot \mathrm{mol}^{-1}\right)$, was found less stable by 5.5 $\mathrm{kcal} \cdot \mathrm{mol}^{-1}$. The two other isomers $\mathbf{2}-\mathbf{Z r}-\boldsymbol{C}_{\mathrm{s}}$-down(1) and $\mathbf{2}-\mathbf{Z r}-\boldsymbol{C}_{\mathbf{1}}$-down with the down orientation of $\left[\mathrm{BnB}\left(\mathrm{C}_{6} \mathrm{~F}_{5}\right)_{3}\right]^{-}$anion appeared to be only by 0.6 and $3.6 \mathrm{kcal} \cdot \mathrm{mol}^{-1}$ disfavored with respect to the 
reference molecule. Given the presumably low rotation barrier of the $\pi$-Ph coordinated anion $\left[\mathrm{BnB}\left(\mathrm{C}_{6} \mathrm{~F}_{5}\right)_{3}\right]^{-}$in the coordination sphere of the cationic metal center, interconversion between the up and down forms of either $\mathbf{2}-\mathbf{Z r}-\boldsymbol{C}_{\mathbf{s}}$ or $\mathbf{2}-\mathbf{Z r}-\boldsymbol{C}_{\mathbf{1}}$ isomers should be rapid on the NMR time scale. Thus, observation in the NMR spectra of $\mathbf{2 - Z r}$ (vide supra) of only two species of $C_{\mathrm{s}^{-}}$and $C_{1^{-}}$ symmetry is in complete agreement with this hypothesis. Hence, $\mathbf{2}-\mathbf{Z r} \mathbf{C} \boldsymbol{C} \mathbf{1}-\mathbf{d o w n}(\mathbf{1})$ isomer can also be the $C_{1}$-symmetric species observed by VT NMR spectroscopy that makes the energy difference

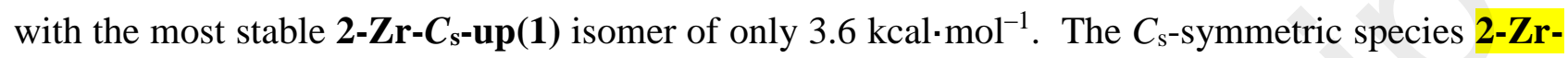
$\boldsymbol{C}_{\mathrm{s}}-\mathbf{u p}(\mathbf{2})$ and $\mathbf{2 - Z r}-\boldsymbol{C}_{\mathrm{s}}-\mathbf{d o w n}(2)$ exhibiting a different conformation of the $\{\mathrm{ONO}\}^{2-}$ ligand were computed to be destabilized each by $c a .6 \mathrm{kcal} \cdot \mathrm{mol}^{-1}$. Also, the calculations confirmed the

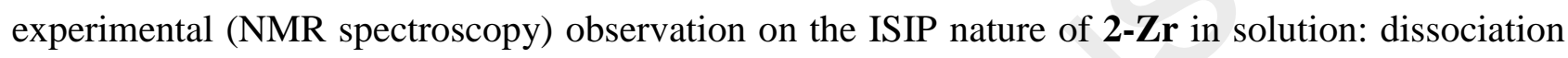
of both $C_{\mathrm{s}^{-}}$and $C_{1^{-}}$-symmetric ion pairs leading to the OSIP specimen $\mathbf{2}-\mathbf{Z r}-\boldsymbol{C}_{\mathrm{s}^{-}}$-decoord(1,2) and 2Zr-C1-decoord was found endergonic by $4.8,6.2$ and $9.6 \mathrm{kcal} \cdot \mathrm{mol}^{-1}$, respectively.

For the 2-Ti system, the most stable isomer appeared to be the dissociated $C_{\mathrm{s}}$-symmetric OSIP 2-Ti- $\boldsymbol{C}_{\mathbf{s}}$-decoord. This finding is also consistent with the ${ }^{19} \mathrm{~F}$ NMR spectroscopic data evidencing the existence of a dissociated ion-pair in solution (vide supra). On the other hand, isomerization of this $C_{\mathrm{s}}$-symmetric species to the $C_{1}$-symmetric isomer $\mathbf{2}$-Ti- $\boldsymbol{C}_{\mathbf{1}}$-decoord was calculated to be disfavored both thermodynamically and kinetically with the corresponding parameters $\Delta E_{C s \leftrightarrow C 1}$ of $10.2 \mathrm{kcal} \cdot \mathrm{mol}^{-1}$ and $\Delta E_{C s \leftrightarrow C 1}^{\ddagger}$ of $17.2 \mathrm{kcal} \cdot \mathrm{mol}^{-1}$. The three closest computed isomers in terms of energy are the ISIP species $\mathbf{2}-\mathbf{T i}-\boldsymbol{C}_{\mathrm{s}}-\mathbf{u p}(\mathbf{1})$ and $\mathbf{2}-\mathbf{T i}-\boldsymbol{C}_{\mathrm{s}}$-down(1) ( $\Delta E$ $=6.5$ and $7.6 \mathrm{kcal} \cdot \mathrm{mol}^{-1}$, respectively $)$ and an OSIP species 2 -Ti- $C_{\mathrm{s}}$-decoord(2) $(\Delta E=9.2$ $\mathrm{kcal} \cdot \mathrm{mol}^{-1}$ ); the former species would feature a reasonable relative interconversion barrier $\Delta E^{\ddagger} C_{s} \leftrightarrow C 1$ of $12.4 \mathrm{kcal} \cdot \mathrm{mol}^{-1}$ towards the $C_{1}$-symmetric congener $\mathbf{2}$-Ti- $\boldsymbol{C}_{\mathbf{1}}$-up.

The origin of the higher stability (reluctance to re-association) of the titanium-based OSIP 2Ti- $\boldsymbol{C}_{\mathrm{s}}$-decoord(1) vis- $a$-vis its ISIP congener $\mathbf{2}-\mathbf{T i}-\boldsymbol{C}_{\mathrm{s}}-\mathbf{u p}(\mathbf{1})$ for the series of the most stable isomers 2-M- $\boldsymbol{C}_{\mathrm{s}}-\mathbf{u p}(\mathbf{1 , 2}) / \mathbf{2}-\mathrm{M}-\boldsymbol{C}_{\mathrm{s}}-\operatorname{decoord}(\mathbf{1 , 2})$ apparently lies in its intrinsic structure. In each of the DFT optimized structures of $\mathbf{2}-\mathbf{T i}-\boldsymbol{C}_{\mathrm{s}}$-decoord(1) (Fig. S19A), 2-Ti- $\boldsymbol{C}_{\mathbf{1}}$-decoord(2) and 2-Ti- $\boldsymbol{C}_{\mathrm{s}^{-}}$ 
$\operatorname{decoord}(2)$, the virtually four-coordinate cationic metal center features a distorted tetrahedral geometry. Analysis of the electron density showed in all cases that the LUMO located at the metal center (Fig. S19B for $\mathbf{2}$-Ti- $\boldsymbol{C}_{\mathrm{s}}$-decoord(1)) is situated in the wedge between the two Ti-O bond vectors and is thus sterically shielded by the oxygen atoms. ${ }^{17}$ On the other hand, the geometry of the virtually four-coordinate cationic zirconium center in the optimized structures of $\mathbf{2}-\mathbf{Z r} \mathbf{r}-\boldsymbol{C}_{\mathbf{s}^{-}}$

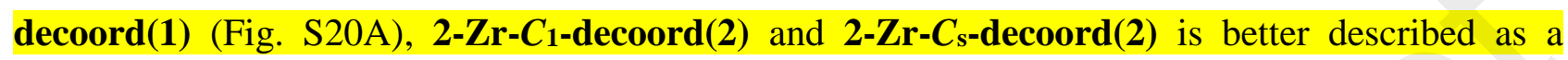
distorted square planar $^{18}$ with the corresponding LUMO (Fig. S20B for $\mathbf{2}-\mathbf{Z r}$ - $\boldsymbol{C}_{\mathbf{s}}$-decoord(1)) pointing in a direction of the open face of the molecule and, thus, is available for attack of a nucleophile (e.g. the $\pi$-system of the benzyl group of $\left.\left[\mathrm{BnB}\left(\mathrm{C}_{6} \mathrm{~F}_{5}\right)_{3}\right]^{-}\right)$.

\section{Synthesis and Structure of Neutral Dichloro Complex $\left\{\mathrm{ONO}^{\mathrm{SiMe} 2 t \mathrm{Bu}}\right\} \mathrm{ZrCl}_{2}\left(\mathrm{Me}_{2} \mathrm{NH}\right)(3)$.}

A catalytic system incorporating a dichloro precursor $\mathbf{3}$ was also targeted with the aim to compare its catalytic behavior (with MAO as activator) with those of discrete alkyl cationic complexes. The synthesis of the neutral dichloro congener $\mathbf{3}$ was performed according to Scheme 3 . Thus, an amine-elimination reaction of proligand $\mathbf{1 - \mathbf { H } _ { 2 }}$ with $\left(\mathrm{Me}_{2} \mathrm{~N}\right)_{2} \mathrm{ZrCl}_{2}(\mathrm{DME})^{19}$ precursor, monitored by ${ }^{1} \mathrm{H}$ NMR spectroscopy at room temperature in $\mathrm{CD}_{2} \mathrm{Cl}_{2}$, afforded quantitatively 3 ; the pure complex was isolated in high yield in a preparative reaction.
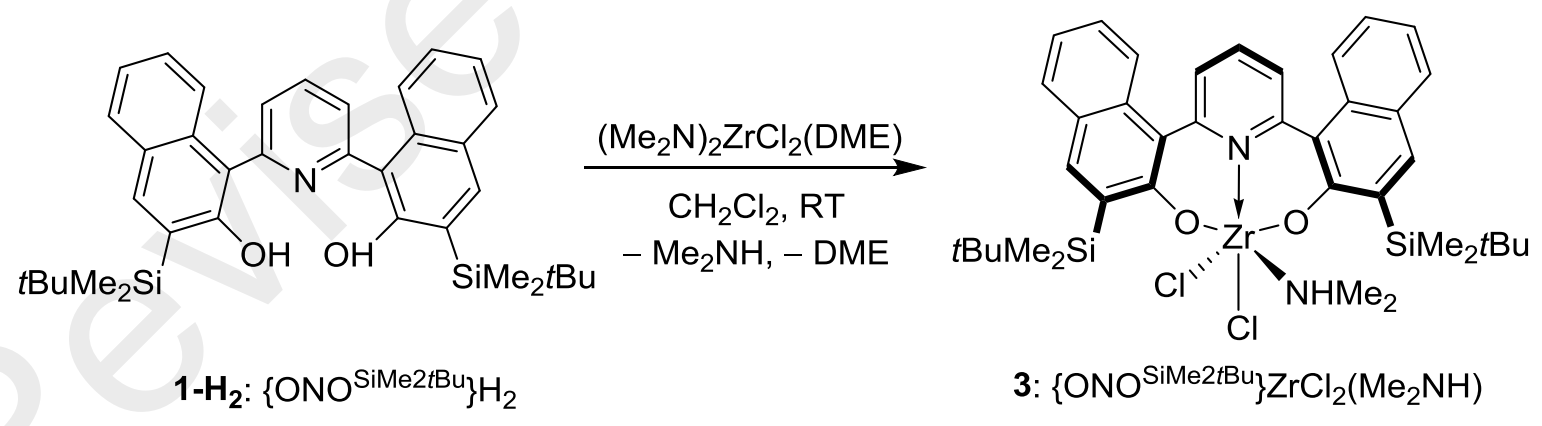

Scheme 3. Synthesis of 3 .

Both the ${ }^{1} \mathrm{H}$ and ${ }^{13} \mathrm{C}$ NMR spectroscopic data for 3 at room temperature in $\mathrm{CD}_{2} \mathrm{Cl}_{2}$ are consistent with the existence, on the NMR time scale, of a single $C_{\mathrm{s}}$-symmetric species (Fig. S13 and S14, respectively). No additional resonances that would account for the presence of another 
stereoisomer were observed neither in the ${ }^{1} \mathrm{H}$ nor in the ${ }^{13} \mathrm{C}\left\{{ }^{1} \mathrm{H}\right\}$ NMR spectrum of this compound upon heating a benzene- $d_{6}$ solution of $\mathbf{3}$ up to $70^{\circ} \mathrm{C}$. The only dynamic behavior observed for $\mathbf{3}$ by VT ${ }^{1} \mathrm{H}$ NMR studies in benzene- $d_{6}$ was coalescence of the resonances from diastereotopic SiMeMe groups into one broad signal $\left(T_{\text {coal }}=c a .50{ }^{\circ} \mathrm{C}\right)$ and some sharpening of the resonances both from aromatic hydrogens and $\mathrm{NHMe}_{2}$ ligand.

In the solid state, the molecule of $\mathbf{3}$ shows a distorted square-bipyramidal geometry at the zirconium center, which is six-coordinated by the $\left\{\mathrm{ONO}^{\mathrm{SiMe} 2 t \mathrm{Bu}}\right\}^{2-}$ ligand, two chlorine and the $\mathrm{NHMe}_{2}$ donor molecule. The coordination of the ligand resembles the one observed in the corresponding structures of neutral 1-Zr and ion-pair 2-Zr: the naphtholate planes twist in the same direction from the plane of the pyridine linker (twist angles between the planes $=49.35$ and $56.80^{\circ}$ ) and give rise to a $C_{\mathrm{s}}$-symmetric structure. Also, the corresponding $\mathrm{Zr}(1)-\mathrm{O}$ and $\mathrm{Zr}(1)-\mathrm{N}$ bond distances in 3 (1.976(3), 1.986(2) and 2.418(3) A, respectively) are unexceptional and compare well with those observed in 1-Zr (1.995(5), 2.018(5) and 2.449(6) $\AA$, respectively). ${ }^{7}$ Bonding of the $\mathrm{NHMe}_{2}$ ligand with the metal center appeared is quite strong, as evidenced from the short $\mathrm{Zr}(1)-\mathrm{N}(2)$ distance $(2.417(4) \AA)$ that is very close to that of $\mathrm{Zr}(1)-\mathrm{N}($ pyridine $)(2.418(3) \AA$ ).

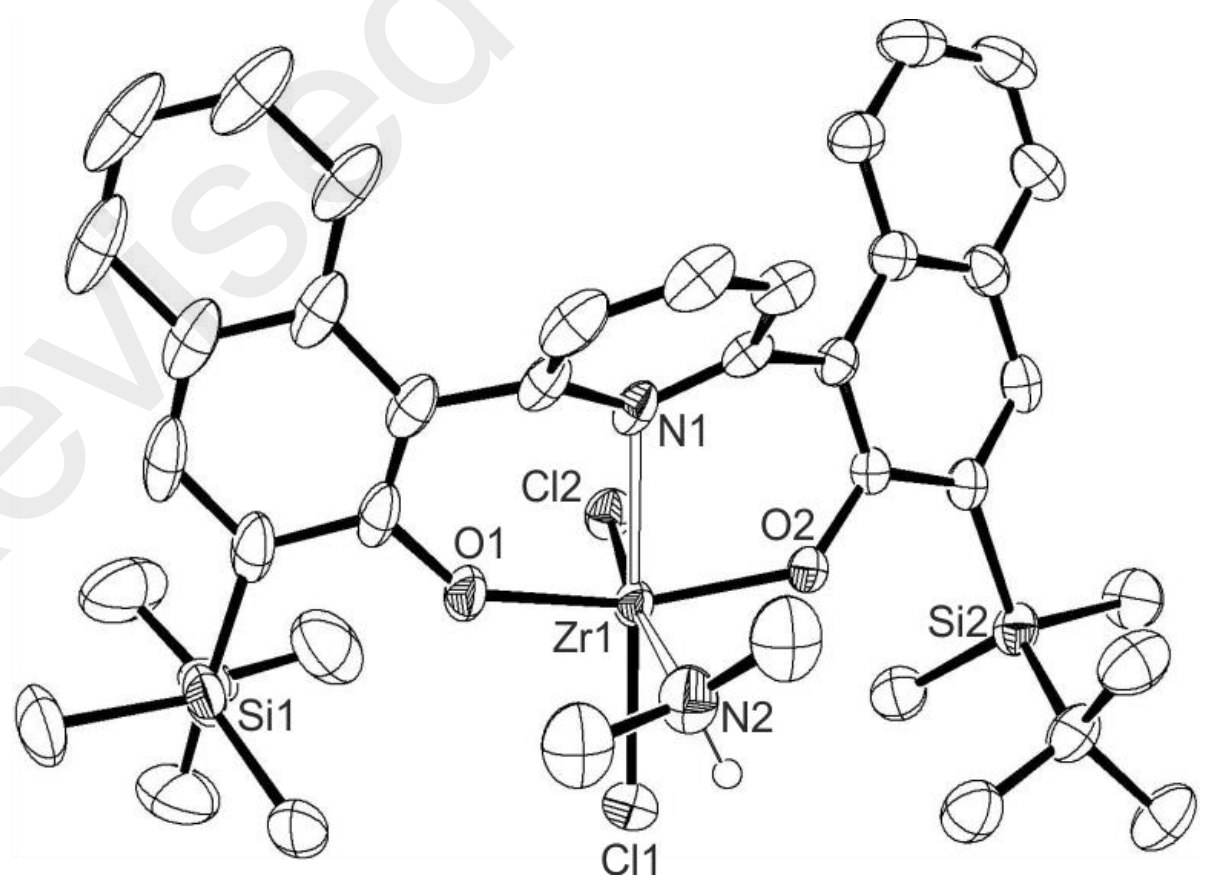


Figure 2. Molecular structure of $\left\{\mathrm{ONO}^{\mathrm{SiMe} 2 t \mathrm{Bu}}\right\} \mathrm{ZrCl}_{2}\left(\mathrm{NHMe}_{2}\right)\left(3 \cdot 7 / 3 \mathrm{C}_{6} \mathrm{H}_{6}\right)$ (all hydrogen atoms, except that one of the $\mathrm{NHMe}_{2}$ ligand, are omitted for clarity; thermal ellipsoids drawn at the 50\% probability). Selected bond distances $(\AA)$ and angles $\left(^{\circ}\right)$ : $\operatorname{Zr}(1)-\mathrm{O}(1), 1.976(3), \operatorname{Zr}(1)-\mathrm{O}(2)$, 1.986(2); $\mathrm{Zr}(1)-\mathrm{N}(1), 2.418(3) ; \quad \mathrm{Zr}(1)-\mathrm{N}(2), 2.417(4) ; \mathrm{Zr}(1)-\mathrm{Cl}(1), 2.4307(12) ; \mathrm{Zr}(1)-\mathrm{Cl}(2)$, $2.4185(10) ; \quad \mathrm{N}(1)-\mathrm{Zr}(1)-\mathrm{Cl}(1), \quad 170.33(8) ; \quad \mathrm{O}(1)-\mathrm{Zr}(1)-\mathrm{O}(2), \quad 156.37(12) ; \quad \mathrm{N}(2)-\mathrm{Zr}(1)-\mathrm{Cl}(2)$, 173.30(9).

Preliminary studies on the polymerization activity. The catalytic performance of the isolated discrete ionic complexes 2-Ti and 2-Zr or those generated in situ from the charge neutral 1Ti and 1-Zr and the corresponding molecular co-catalysts $\left(\mathrm{B}\left(\mathrm{C}_{6} \mathrm{~F}_{5}\right)_{3},\left[\mathrm{Ph}_{3} \mathrm{C}\right]^{+}\left[\mathrm{B}\left(\mathrm{C}_{6} \mathrm{~F}_{5}\right)_{4}\right]^{-}\right),{ }^{11}$ briefly evaluated in the homogeneous polymerization of propylene and styrene, was found sluggish (see the SI for more details; Tables S2 and S3). The combination 3/MAO showed a modest productivity in propylene polymerization $\left(135 \mathrm{~kg}(\mathrm{PP}) \cdot \mathrm{mol}(\mathrm{Zr})^{-1} \cdot \mathrm{h}^{-1}\right.$ over $1 \mathrm{~h}$ at $50{ }^{\circ} \mathrm{C}$; Table $\mathrm{S} 2$, entry 2$)$. The material recovered was an oily product, readily soluble in toluene and hardly precipitated by addition of methanol. This product was analyzed by GPC and ${ }^{1} \mathrm{H}$ and ${ }^{13} \mathrm{C}\left\{{ }^{1} \mathrm{H}\right\}$ NMR spectroscopy. In contrast with the 1-Zr/MAO analogue, which afforded polypropylenes with bimodal distributions (typically composed of two relatively narrow fractions with $M_{\mathrm{n}}=720-800$ and $116,000-140,000 \mathrm{~g} \cdot \mathrm{mol}^{-1}$, respectively, and $\left.M_{\mathrm{w}} / M_{\mathrm{n}}=1.2-1.5\right),{ }^{7}$ the polymer obtained with $3 / \mathrm{MAO}$ featured narrow monomodal distribution consistent with a single-site behavior. Intense olefinic resonances in the downfield regions of both ${ }^{1} \mathrm{H}$ (Fig. S15) and ${ }^{13} \mathrm{C}$ NMR spectra at $\delta 4.74$ and 4.67 ppm $(\delta 144.9 \text { and } 111.2 \mathrm{ppm})^{7}$ are diagnostic of vinylidenic $\mathrm{CH}_{2}=\mathrm{CH}\left(\mathrm{CH}_{3}\right)$ - end-groups and, hence, predominant termination reaction by $\beta-\mathrm{H}$ elimination. Assuming that each chain of this low molecular weight polymer $\left(M_{\mathrm{n}, \mathrm{GPC}}=1,400 \mathrm{~g} \cdot \mathrm{mol}^{-1}\right)$ is vinylidene-terminated, the $M_{\mathrm{n}}$ value estimated by NMR was $920 \mathrm{~g} \cdot \mathrm{mol}^{-1}$. The complex pattern of signals in the aliphatic region of the ${ }^{13} \mathrm{C}$ NMR spectrum at $\delta 27.0-27.8 \mathrm{ppm}$ (Fig. S16) was found to be very similar to that of low 
molecular weight polypropylenes obtained with $\mathbf{1 - Z r} / \mathrm{MAO},{ }^{7}$ and also corresponds to a regioirregular microstructure.

Activation of $\mathbf{3}$ with $\mathrm{MAO}$ at $50{ }^{\circ} \mathrm{C}$ afforded a system more active towards styrene (Table S3, entry 15$)$ that produced low molecular weight polystyrene $\left(M_{\mathrm{n}}=9,900 \mathrm{~g} \cdot \mathrm{mol}^{-1}\right)$. Interestingly, the relatively narrow polydispersity $\left(M_{\mathrm{w}} / M_{\mathrm{n}}=1.2\right)$ suggests a "living" character of the catalytic system. In the aromatic ipso-carbon region of the high-field ${ }^{13} \mathrm{C}\left\{{ }^{1} \mathrm{H}\right\}$ NMR spectrum of this sample (Fig. S17), ${ }^{20}$ the pattern of the four distinct signals from $r r m r r r, r m r r r, r r r r r$ and $m r r r r$ heptads is fully consistent with the one of syndiotactic-enriched polystyrenes obtained via chain-end control mechanism. ${ }^{20,21}$ A moderate but significant syndioselectivity in terms of $[r]^{6}$ heptad content of $58 \%$ was calculated from the relative intensities of the corresponding signals. No melting transition was observed by DSC for this polymer, likely a consequence of its low molecular weight. However, despite these stereoselective abilities of the 3/MAO system in styrene polymerization, no correlation between the dynamic behavior of the compounds and their polymerization behavior could be established thus far.

\section{Conclusions}

Cationic ion-pairs 2-Ti and 2-Zr derived from their parent neutral complexes $\mathbf{1 - T i}$ and $\mathbf{1 - Z r}$ have been prepared and their structures in solution and in the solid state have been investigated. The ISIP 2-Zr retains in solution the associated structure, observed in the solid state; on the other hand, the 2-Ti analogue, also associated in the solid state, apparently dissociates in solution. The latter fact was also corroborated by thermochemical DFT calculations. The complex dynamic behavior observed for $\mathbf{2}$-Ti in solution, likely involving several species, may comprise at least two phenomena: rearrangement of the ion pair and interconversion ("oscillation") between different forms having either rac- or meso-like coordination modes of the $\left\{\mathrm{ONO}^{\mathrm{SiMe} 2 t \mathrm{Bu}}\right\}^{2-}$ ligand. For the ion pair 2-Zr, such interconversion between two isomeric forms featuring $C_{1}$ - and $C_{\mathrm{s}}$-symmetries was found to proceed without dissociation. The corresponding DFT calculated interconversion 
barrier, $\Delta E_{C s \leftrightarrow C 1}^{\neq}=13.8 \mathrm{kcal} \cdot \mathrm{mol}^{-1}$, is somewhat superior to that calculated for the neutral $\mathbf{1 - Z \mathbf { r }}$ precursor $\left(12.5 \mathrm{kcal} \cdot \mathrm{mol}^{-1}\right){ }^{7}$ No similar process was detected for neutral dichloro $\mathrm{Me}_{2} \mathrm{NH}$-adduct 3. This may be tentatively accounted for the saturated coordination sphere of this neutral complex,

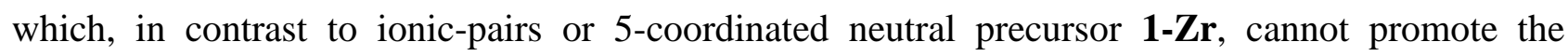
aforementioned rearrangement and/or interconversion processes.

The isolated cationic complexes $\mathbf{2 - T i}$ and $\mathbf{2 - Z \mathbf { r }}$ and their in situ generated versions were found poorly active in polymerization of propylene and styrene. On the other hand, 3/MAO was capable to produce low molecular weight atactic regioirregular polypropylene and syndiotacticenriched polystyrene, yet with low productivities.

Further modifications of the $\{\mathrm{ONO}\}^{2-}$ ligand systems and investigations on the reactivity of cationic species derived thereof are underway in our laboratories.

\section{Experimental Section}

General Considerations. All manipulations were performed under a purified argon atmosphere using standard Schlenk techniques or in a glovebox. Solvents were distilled from $\mathrm{Na} /$ benzophenone $\left(\mathrm{THF}, \mathrm{Et}_{2} \mathrm{O}\right.$ ) and $\mathrm{Na} / \mathrm{K}$ alloy (toluene, pentane) under nitrogen, degassed thoroughly and stored under nitrogen prior to use. Deuterated solvents (benzene- $d_{6}$, toluene- $d_{8}$, THF- $d_{8} ;>99.5 \%$ D, Eurisotop) were vacuum-transferred from $\mathrm{Na} / \mathrm{K}$ alloy into storage tubes; $\mathrm{CD}_{2} \mathrm{Cl}_{2}$ was dried over molecular sieves $3 \mathrm{~A}$ and kept under $\operatorname{argon}$. $\left(\mathrm{Me}_{2} \mathrm{~N}\right)_{2} \mathrm{ZrCl}_{2}(\mathrm{DME})^{19}$ and $\left\{\mathrm{ONO}^{\mathrm{SiMe} 2 t \mathrm{Bu}}\right\} \mathrm{H}_{2}\left(\mathbf{1 - \mathrm { H } _ { 2 }}\right),\left\{\mathrm{ONO}^{\mathrm{SiMe} 2 t \mathrm{Bu}}\right\} \mathrm{M}\left(\mathrm{CH}_{2} \mathrm{Ph}\right)_{2}(\mathrm{M}=\mathrm{Ti}(\mathbf{1 - T i}), \mathrm{Zr}(\mathbf{1 - Z r}))^{7}$ precursors, were prepared using reported procedures. Other starting materials were purchased from Acros, Strem and Aldrich, and used as received.

NMR spectra of complexes were recorded on Bruker AC-200, AC-300, Avance DRX 400 and AM-500 spectrometers in Teflon-valved NMR tubes at $298 \mathrm{~K}$ unless otherwise indicated. ${ }^{1} \mathrm{H}$ and ${ }^{13} \mathrm{C}$ NMR chemical shifts are reported in ppm vs. $\mathrm{SiMe}_{4}$ and were determined by reference to the residual solvent peaks. Assignment of resonances for organometallic complexes was made from 
2D ${ }^{1} \mathrm{H}-{ }^{1} \mathrm{H}$ COSY and ${ }^{1} \mathrm{H}-{ }^{13} \mathrm{C}$ HMQC and HMBC NMR experiments. Elemental analyses $(\mathrm{C}, \mathrm{H}, \mathrm{N})$ were performed using a Flash EA1112 CHNS Thermo Electron apparatus and are the average of two independent determinations.

Average molar mass ( $\overline{\mathrm{M}} \mathrm{SEC})$ and molar mass distribution ( $\overline{\mathrm{M}} \mathrm{w} / \overline{\mathrm{M}} \mathrm{n})$ values were determined by $\mathrm{SEC}$ in $\mathrm{THF}$ at $30{ }^{\circ} \mathrm{C}$ (flow rate $=1.0 \mathrm{~mL} \cdot \mathrm{min}^{-1}$ ) vs. polystyrene standards on a Polymer Laboratories PL50 apparatus equipped with a refractive index detector and two ResiPore $300 \times 7.5 \mathrm{~mm}$ columns. The polymer samples were dissolved in THF $\left(2 \mathrm{mg} \cdot \mathrm{mL}^{-1}\right)$.

$\left\{\mathrm{ONO}^{\mathrm{SiMe} 2 t \mathrm{Bu}}\right\} \mathrm{Ti}\left(\mathrm{CH}_{2} \mathrm{Ph}\right)\left(\left(\eta^{6}-\mathrm{Ph}\right) \mathrm{CH}_{2} \mathrm{~B}\left(\mathrm{C}_{6} \mathrm{~F}_{5}\right) 3\right)$ (2-Ti). A Schlenk flask was charged with \{ONO $\left.^{\text {SiMe } 2 t \mathrm{Bu}}\right\} \mathbf{T i}\left(\mathrm{CH}_{2} \mathbf{P h}\right)_{2}(0.100 \mathrm{~g}, 0.122 \mathrm{mmol})$ and $\mathrm{B}\left(\mathrm{C}_{6} \mathrm{~F}_{5}\right)_{3}(0.063 \mathrm{~g}, 0.123 \mathrm{mmol})$, and toluene $(5 \mathrm{~mL})$ was vacuum-transferred in. The reaction mixture was stirred overnight at room temperature, and evaporated to dryness to afford 2-Ti as a brown-orange solid $(0.154 \mathrm{~g}, 0.116 \mathrm{mmol}, 95 \%) .{ }^{1} \mathrm{H}$ $\operatorname{NMR}\left(500 \mathrm{MHz}\right.$, toluene- $\left.d_{8}, 25{ }^{\circ} \mathrm{C}\right): \delta 8.29(\mathrm{~s}, 2 \mathrm{H}), 7.63-7.74(\mathrm{~m}, 6 \mathrm{H}), 7.44(\mathrm{t}, J=7.4,2 \mathrm{H}), 7.20$ $\left(\mathrm{d}, J=7.3,2 \mathrm{H}, o-P h \mathrm{CH}_{2} \mathrm{Zr}\right), 7.03$ (t, 1H, $p$-Py, overlapped with the signal from solvent), 6.95 (t, $J=$ 7.3, 2H, $m-P h \mathrm{CH}_{2} \mathrm{Zr}$ ), $6.90(\mathrm{t}, J=8.1,2 \mathrm{H}, m-\mathrm{Py}), 6.80\left(\mathrm{t}, J=7.3,1 \mathrm{H}, p-P h \mathrm{CH}_{2} \mathrm{Zr}\right.$ ), 6.62 (br t, $1 \mathrm{H}$, $p-P h \mathrm{CH}_{2} \mathrm{~B}$ ), 6.09 (br t, 2H, $m-\mathrm{PhCH}_{2} \mathrm{~B}$ ), 5.20 (br d, $2 \mathrm{H}, o-P h \mathrm{CH}_{2} \mathrm{~B}$ ), 3.39 (br s, $2 \mathrm{H}, \mathrm{PhCH}_{2} \mathrm{Zr}$ ), 3.00 (br s, $2 \mathrm{H}, \mathrm{PhCH} \mathrm{H}_{2} \mathrm{~B}$ ), 1.04 (br s, $18 \mathrm{H}, t \mathrm{Bu}$ ), 0.66 (s, 6H, SiMeMe), 0.66 (s, 6H, SiMeMe). ${ }^{13} \mathrm{C}\left\{{ }^{1} \mathrm{H}\right\}$ NMR (125 MHz, toluene- $\left.d_{8}, 25^{\circ} \mathrm{C}\right): \delta 156.7(\mathrm{C}-\mathrm{O}), 150.7(\mathrm{C}-\mathrm{N}), 149.0\left(\mathrm{C}_{\text {ipso }}, \mathrm{PhCH}_{2} \mathrm{Zr}\right), 148.7$ (br $\left.\mathrm{d},{ }^{1} J=236, o-\mathrm{C}_{6} \mathrm{~F}_{5}\right), 145.0\left(\mathrm{br} \mathrm{m},{ }^{1} J=268, p-\mathrm{C}_{6} \mathrm{~F}_{5}\right), 144.4,136.7\left(\mathrm{br} \mathrm{m},{ }^{1} J=245, m-\mathrm{C}_{6} \mathrm{~F}_{5}\right), 132.8$, $132.7,131.9,131.4,131.3,131.2,131.1,129.9,129.5,128.9,128.5,128.1,127.0,126.7,125.0$, 122.5, 117.7, $96.0\left(\mathrm{PhCH}_{2} \mathrm{~B}\right), 32.0\left(\mathrm{PhCH}_{2} \mathrm{Zr}\right), 26.7\left(\mathrm{CCH}_{3}\right), 17.4\left(\mathrm{CCH}_{3}\right),-3.1\left(\mathrm{SiCH}_{3}\right),-5.1$ $\left(\mathrm{SiCH}_{3}\right) .{ }^{11} \mathrm{~B}\left\{{ }^{1} \mathrm{H}\right\} \mathrm{NMR}\left(128 \mathrm{MHz}\right.$, toluene- $\left.d_{8}, 25{ }^{\circ} \mathrm{C}\right): \delta-12.2 .{ }^{19} \mathrm{~F}\left\{{ }^{1} \mathrm{H}\right\}$ NMR $(376 \mathrm{MHz}$, toluene$\left.d_{8}, 25^{\circ} \mathrm{C}\right): \delta-129.9\left(\mathrm{~d}, J=20.5,6 \mathrm{~F}, o-\mathrm{C}_{6} \mathrm{~F}_{5}\right),-164.2\left(\mathrm{~d}, J=20.5,3 \mathrm{~F}, p-\mathrm{C}_{6} \mathrm{~F}_{5}\right),-166.8(\mathrm{~d}, J=20.5$, 6F, $\left.m-\mathrm{C}_{6} \mathrm{~F}_{5}\right) .{ }^{29} \mathrm{Si}\left\{{ }^{1} \mathrm{H}\right\} \quad \mathrm{NMR}\left(79 \mathrm{MHz}\right.$, toluene- $\left.d_{8}, 25{ }^{\circ} \mathrm{C}\right): \delta \quad 6.02 . \quad$ Anal. calcd. for $\mathrm{C}_{69} \mathrm{H}_{57} \mathrm{BF}_{15} \mathrm{NO}_{2} \mathrm{Si}_{2} \mathrm{Ti}: \mathrm{C}, 62.22 ; \mathrm{H}, 4.31 ; \mathrm{N}, 1.05$. Found: C, 62.45; H, 4.56; N, 1.17.

$\left\{\mathrm{ONO}^{\mathrm{SiMe} 2 t \mathrm{Bu}}\right\} \mathrm{Zr}\left(\mathrm{CH}_{2} \mathrm{Ph}\right)\left(\left(\eta^{6}-\mathrm{Ph}\right) \mathrm{CH}_{2} \mathrm{~B}\left(\mathrm{C}_{6} \mathbf{F}_{5}\right) 3\right)$ (2-Zr). Using a protocol similar to that described above for 2-Ti, compound 2-Zr was prepared from $\left\{\mathbf{O N O}^{\text {SiMe } 2 t \mathbf{B u}}\right\} \mathbf{Z r}\left(\mathbf{C H}_{2} \mathbf{P h}\right)_{2}(0.100 \mathrm{~g}$, 
$0.116 \mathrm{mmol})$ and $\mathrm{B}\left(\mathrm{C}_{6} \mathrm{~F}_{5}\right)_{3}(0.060 \mathrm{~g}, 0.117 \mathrm{mmol})$ and isolated as a yellow-orange solid $(0.152 \mathrm{~g}$, $0.111 \mathrm{mmol}, 96 \%) .{ }^{1} \mathrm{H} \mathrm{NMR}\left(500 \mathrm{MHz}\right.$, toluene- $\left.d_{8}, 25{ }^{\circ} \mathrm{C}\right)$ (signals from three aromatic hydrogens overlapped with those from solvent): $\delta 8.08$ (br s, 2H), 7.60 (br m, 6H), 7.21 (br m, 6H), 6.86 (br m, 2H), 6.71 (br m, 1H), 6.42 (br m, Ph), 5.74 (br m, 2H, Ph), 5.61 (br t, 1H, $p-P h \mathrm{CH}_{2} \mathrm{Zr}$ ), 3.13 (br s, 2H, $\mathrm{PhCH}_{2}$ ), 2.98 (br s, 2H, $\mathrm{PhCH}_{2}$ ), 1.02 (br s, 18H, tBu), 0.64 (s, 6H, SiMeMe), 0.53 (s, 6H, SiMeMe). ${ }^{11} \mathrm{~B}\left\{{ }^{1} \mathrm{H}\right\}$ NMR (128 MHz, toluene- $\left.d_{8}, 25{ }^{\circ} \mathrm{C}\right): \delta-12.4 . \quad{ }^{19} \mathrm{~F}\left\{{ }^{1} \mathrm{H}\right\}$ NMR $(376 \mathrm{MHz}$, toluene- $\left.d_{8}, 25^{\circ} \mathrm{C}\right): \delta-129.8$ (br d, 6F, $\left.o-\mathrm{C}_{6} \mathrm{~F}_{5}\right),-162.3$ (br m, 3F, $p-\mathrm{C}_{6} \mathrm{~F}_{5}$ ), -165.5 (br m, 6F, $m$ $\left.\mathrm{C}_{6} \mathrm{~F}_{5}\right) .{ }^{29} \mathrm{Si}\left\{{ }^{1} \mathrm{H}\right\}$ NMR $\left(79 \mathrm{MHz}\right.$, toluene- $\left.d_{8}, 25{ }^{\circ} \mathrm{C}\right): \delta 3.4 . C_{1}$-symmetric species (many signals overlapped with those from the solvent; some signals obscured by those of another species): ${ }^{1} \mathrm{H}$ NMR $\left(500 \mathrm{MHz}\right.$, toluene- $\left.d_{8},-50{ }^{\circ} \mathrm{C}\right): \delta 8.19\left(\mathrm{~s}, 1 \mathrm{H}, \mathrm{H}^{4}\right), 7.90($ br d, $J=7.9,1 \mathrm{H}), 7.87\left(\mathrm{~s}, 1 \mathrm{H}, \mathrm{H}^{4}\right)$, $7.53(\mathrm{~m}, 1 \mathrm{H}), 7.44(\mathrm{~m}, 1 \mathrm{H}), 7.03\left(\mathrm{~m}, 2 \mathrm{H}, P h \mathrm{CH}_{2}\right), 6.98$ (br d, $\left.J=6.5,1 \mathrm{H}, P h \mathrm{CH}_{2}\right), 6.90$ (br m, 1H, $\left.P h \mathrm{CH}_{2}\right), 6.72\left(\mathrm{~d}, J=8.0,2 \mathrm{H}, o-P h \mathrm{CH}_{2}\right), 6.44\left(\mathrm{br} \mathrm{m}, 1 \mathrm{H}, P h \mathrm{CH}_{2}\right), 6.40(\mathrm{t}, J=8.0,2 \mathrm{H}), 6.24($ br t, $J$ $\left.=6.5,1 \mathrm{H}, P h \mathrm{CH}_{2}\right), 5.72\left(\right.$ br m, 1H, $\left.P h \mathrm{CH}_{2}\right), 3.69$ (br m, 1H, PhCHHB), 3.60 (br m, 1H, PhCHHB), 3.08 (br d, $J=10.1,1 \mathrm{H}, \mathrm{PhC} \underline{H} H Z r), 2.96$ (br d, $J=10.1,1 \mathrm{H}, \mathrm{PhCH} H Z r$ ), 1.07 (s, 9H, $t \mathrm{Bu}$ ), 0.93 (s, 9H, $t \mathrm{Bu}), 0.63(\mathrm{~s}, 3 \mathrm{H}, \mathrm{Me}), 0.60(\mathrm{~s}, 3 \mathrm{H}, \mathrm{Me}), 0.59$ (s, 3H, Me), $0.52(\mathrm{~s}, 3 \mathrm{H}, \mathrm{Me}) .{ }^{13} \mathrm{C}\left\{{ }^{1} \mathrm{H}\right\} \mathrm{NMR}$ $\left(125 \mathrm{MHz}\right.$, toluene- $\left.d_{8},-50{ }^{\circ} \mathrm{C}\right): \delta 161.3(\mathrm{C}-\mathrm{O}), 159.0(\mathrm{C}-\mathrm{O}), 147.3\left(\mathrm{br} \mathrm{m},{ }^{1} J=243, o-\mathrm{C}_{6} \mathrm{~F}_{5}\right), 143.8$ $\left(\mathrm{C}^{4}\right), 140.7\left(\mathrm{C}^{4}\right), 137.8$ (br m, $\left.{ }^{1} J=219, p-\mathrm{C}_{6} \mathrm{~F}_{5}\right), 137.3\left(P h^{2} \mathrm{CH}_{2}\right), 136.2\left(\mathrm{br} \mathrm{m},{ }^{1} J=249, m-\mathrm{C}_{6} \mathrm{~F}_{5}\right)$, 132.1 $\left(P h^{1} \mathrm{CH}_{2}\right), 131.6\left(P h^{1} \mathrm{CH}_{2}\right), 131.5\left(P h^{1} \mathrm{CH}_{2}\right), 130.5\left(P h^{2} \mathrm{CH}_{2}\right), \quad 128.9,128.0,122.9,122.1$ $\left(P h^{1} \mathrm{CH}_{2}\right), 78.3\left(\mathrm{PhCH}_{2} \mathrm{Zr}\right), 35.4\left(\mathrm{PhCH}_{2} \mathrm{~B}\right), 26.6\left(\mathrm{CCH}_{3}\right), 26.5\left(\mathrm{CCH}_{3}\right), 17.7\left(\mathrm{CCH}_{3}\right), 17.6\left(\mathrm{CCH}_{3}\right)$, -3.26 $\left(\mathrm{SiCH}_{3}\right),-3.57\left(\mathrm{SiCH}_{3}\right),-3.87\left(\mathrm{SiCH}_{3}\right),-5.02\left(\mathrm{SiCH}_{3}\right) .{ }^{11} \mathrm{~B}\left\{{ }^{1} \mathrm{H}\right\} \mathrm{NMR}\left(128 \mathrm{MHz}\right.$, toluene- $d_{8}$, $\left.-50{ }^{\circ} \mathrm{C}\right): \delta-11.8 .{ }^{19} \mathrm{~F}\left\{{ }^{1} \mathrm{H}\right\}$ NMR $\left(376 \mathrm{MHz}\right.$, toluene- $\left.d_{8},-50{ }^{\circ} \mathrm{C}\right): \delta-129.8\left(\mathrm{br} \mathrm{m}, 6 \mathrm{~F}, o-\mathrm{C}_{6} \mathrm{~F}_{5}\right),-$ 160.8 (br m, 3F, $p-\mathrm{C}_{6} \mathrm{~F}_{5}$ ), -164.3 (br m, 6F, $m-\mathrm{C}_{6} \mathrm{~F}_{5}$ ). ${ }^{29} \mathrm{Si}\left\{{ }^{1} \mathrm{H}\right\}$ NMR $\left(79 \mathrm{MHz}\right.$, toluene- $d_{8},-50{ }^{\circ} \mathrm{C}$ ): $\delta 4.5(\mathrm{~s}, 1 \mathrm{Si}), 3.4(\mathrm{~s}, 1 \mathrm{Si}) . \quad C_{\mathrm{s}}$-symmetric species (many signals overlapped with those from the solvent; some signals obscured by those of another species): ${ }^{1} \mathrm{H}$ NMR (500 MHz, toluene- $d_{8},-50$ $\left.{ }^{\circ} \mathrm{C}\right): \delta 8.12\left(\mathrm{~s}, 2 \mathrm{H}, \mathrm{H}^{4}\right), 7.58(\mathrm{~d}, J=8.0,2 \mathrm{H}), 7.51(\mathrm{~m}, 2 \mathrm{H}), 7.40(\mathrm{~d}, J=8.0,2 \mathrm{H}), 6.76(\mathrm{~d}, J=7.5$, 2H), $6.31\left(\mathrm{~d}, J=7.6,2 \mathrm{H}, o-P h \mathrm{CH}_{2}\right), 6.14(\mathrm{br} \mathrm{m}, 2 \mathrm{H}), 5.62(\mathrm{t}, J=7.1,2 \mathrm{H}), 5.47(\mathrm{t}, J=7.6,1 \mathrm{H}, p-$ 
$P h \mathrm{CH}_{2}$ ), 5.39 (d, $\left.J=7.6,2 \mathrm{H}, m-P h \mathrm{CH}_{2}\right), 3.26$ (br m, 2H, PhCHHB), 2.49 (br m, 2H, PhC $\underline{H H Z r}$ ), $1.09(\mathrm{~s}, 18 \mathrm{H}, t \mathrm{Bu}), 0.69(\mathrm{~s}, 6 \mathrm{H}, \mathrm{Me}), 0.49(\mathrm{~s}, 6 \mathrm{H}, \mathrm{Me}) .{ }^{13} \mathrm{C}\left\{{ }^{1} \mathrm{H}\right\}$ NMR (125 MHz, toluene-d8, -50 $\left.{ }^{\circ} \mathrm{C}\right): \delta 158.6(\mathrm{C}-\mathrm{O}), 147.3\left(\mathrm{~m},{ }^{1} J=243, o-\mathrm{C}_{6} \mathrm{~F}_{5}\right), 141.3\left(\mathrm{C}^{4}\right), 137.8\left(\mathrm{~m},{ }^{1} \mathrm{~J}=225, p-\mathrm{C}_{6} \mathrm{~F}_{5}\right), 136.2(\mathrm{~m}$, $\left.{ }^{1} J=249, m-\mathrm{C}_{6} \mathrm{~F}_{5}\right), 135.1\left(o-P h \mathrm{CH}_{2}\right), 131.5,128.9,127.9\left(m-P h \mathrm{CH}_{2}\right), 127.8,127.4,126.5(p-$ $\left.P h \mathrm{CH}_{2}\right), 125.0,124.9,69.6(\mathrm{PhCH} 2 \mathrm{Zr}), 26.2\left(\mathrm{CCH}_{3}\right),-2.94\left(\mathrm{SiCH}_{3}\right),-3.88\left(\mathrm{SiCH}_{3}\right) .{ }^{11} \mathrm{~B}\left\{{ }^{1} \mathrm{H}\right\} \mathrm{NMR}$ $\left(128 \mathrm{MHz}\right.$, toluene- $\left.d_{8},-50{ }^{\circ} \mathrm{C}\right): \delta-12.2 .{ }^{19} \mathrm{~F}\left\{{ }^{1} \mathrm{H}\right\}$ NMR $\left(376 \mathrm{MHz}\right.$, toluene- $\left.d_{8},-50{ }^{\circ} \mathrm{C}\right): \delta-130.1$ (br m, 6F, o-C6F5), -160.8 (br m, 3F, p-C6F5), -164.8 (br m, 6F, $m$-C6F5). ${ }^{29} \mathrm{Si}\left\{{ }^{1} \mathrm{H}\right\}$ NMR (79 $\mathrm{MHz}$, toluene- $\left.d_{8},-50{ }^{\circ} \mathrm{C}\right): \delta 3.5$ (s, 2Si). Anal. calcd. for $\mathrm{C}_{69} \mathrm{H}_{57} \mathrm{BF}_{15} \mathrm{NO}_{2} \mathrm{Si}_{2} \mathrm{Zr}: \mathrm{C}, 60.24 ; \mathrm{H}, 4.18$; N, 1.02. Found: C, $60.51 ; \mathrm{H}, 4.48 ; \mathrm{N}, 1.20$.

$\left\{\mathrm{ONO}^{\mathrm{SiMe} 2 t \mathrm{Bu}_{\mathbf{Z}}} \mathrm{ZrCl}_{2}\left(\mathrm{HNMe}_{2}\right)\right.$ (3). Protocol A. In the glovebox, a Teflon-valved NMR tube was charged with $\left\{\mathrm{ONO}^{\mathrm{SiMe} 2 t \mathrm{Bu}}\right\} \mathrm{H}_{2}(0.039 \mathrm{~g}, 0.066 \mathrm{mmol})$ and $\left(\mathrm{Me}_{2} \mathrm{~N}\right) \mathrm{ZrCl}_{2}(\mathrm{DME})(0.023 \mathrm{~g}, 0.066$ mmol). To this mixture, $\mathrm{CD}_{2} \mathrm{Cl}_{2}$ (ca. $0.6 \mathrm{~mL}$ ) was vacuum-transferred in and the tube was shaken for $30 \mathrm{~min}$ at room temperature. ${ }^{1} \mathrm{H}$ NMR data indicated that 3 formed quantitatively. ${ }^{1} \mathrm{H}$ NMR $\left(500 \mathrm{MHz}, \mathrm{CD}_{2} \mathrm{Cl}_{2}, 25^{\circ} \mathrm{C}\right): \delta 7.96(\mathrm{~m}, 3 \mathrm{H}), 7.92(\mathrm{~d}, J=8.0,2 \mathrm{H}), 7.72(\mathrm{~d}, J=8.5,2 \mathrm{H}), 7.49(\mathrm{t}, J=$ 8.0, 2H), $7.41(\mathrm{t}, J=8.5,2 \mathrm{H}), 3.53\left(\mathrm{~s}, 4 \mathrm{H}, \mathrm{CH}_{2} \mathrm{OCH}_{3}, \mathrm{DME}\right), 3.38\left(\mathrm{~s}, 6 \mathrm{H}, \mathrm{CH}_{2} \mathrm{OCH}_{3}, \mathrm{DME}\right), 3.37$ (br s, 12H, $\mathrm{NCH}_{3}$ ), 1.10 (s, 18H, $t \mathrm{Bu}$ ), 0.73 (br s, 6H, Me), 0.59 (br s, 6H, Me). ${ }^{13} \mathrm{C}\left\{{ }^{1} \mathrm{H}\right\} \mathrm{NMR}(125$ $\mathrm{MHz}, \mathrm{CD}_{2} \mathrm{Cl}_{2}, 25{ }^{\circ} \mathrm{C}$ ) (signals from the quaternary carbon atoms of the $t \mathrm{Bu}$ groups were not observed): $\delta 160.1(\mathrm{C}-\mathrm{N}), 159.2(\mathrm{C}-\mathrm{O}), 141.0,138.5,133.7,129.4,128.9,128.2,127.8,127.0$, 123.5, 123.3, 118.3, $71.8\left(\mathrm{CH}_{2} \mathrm{OCH}_{3}, \mathrm{DME}\right), 58.6\left(\mathrm{CH}_{2} \mathrm{OCH}_{3}, \mathrm{DME}\right), 39.5$ (br s, $\left.\mathrm{NCH}_{3}\right), 27.10$ $\left(\mathrm{CCH}_{3}\right), 17.8\left(\mathrm{CCH}_{3}\right),-3.7\left(\mathrm{SiMe}_{2}\right)$.

Protocol B. A Schlenk flask was charged with $\left\{\mathrm{ONO}^{\mathrm{SiMe} 2 \mathrm{Bu}}\right\} \mathrm{H}_{2}(0.309 \mathrm{~g}, 0.522 \mathrm{mmol})$ and $\left(\mathrm{Me}_{2} \mathrm{~N}\right) \mathrm{ZrCl}_{2}$ (DME) $(0.178 \mathrm{~g}, 0.522 \mathrm{mmol})$, and $\mathrm{CH}_{2} \mathrm{Cl}_{2}(5 \mathrm{~mL})$ was vacuum-transferred in. The reaction mixture was stirred overnight at room temperature, filtered, evaporated and dried in vacuo to give 3 as a yellow microcrystalline material $(0.399 \mathrm{~g}, 0.501 \mathrm{mmol}, 96 \%) .{ }^{1} \mathrm{H} \mathrm{NMR}(500 \mathrm{MHz}$, toluene- $\left.d_{8}, 70{ }^{\circ} \mathrm{C}\right): \delta 8.18(\mathrm{~s}, 2 \mathrm{H}), 7.69(\mathrm{~d}, J=8.0,2 \mathrm{H}), 7.52(\mathrm{~d}, J=8.0,2 \mathrm{H}), 7.26(\mathrm{~d}, J=7.7,2 \mathrm{H})$, 7.26-7.14 (m, 4H), 7.07 (t, $J=7.7,1 \mathrm{H}), 1.87$ (br s, 12H, NCH $), 1.19$ (s, 18H, $t \mathrm{Bu}), 0.74$ (br s, 12H, 
Me). ${ }^{13} \mathrm{C}\left\{{ }^{1} \mathrm{H}\right\}$ NMR (125 MHz, toluene- $\left.d_{8}, 70{ }^{\circ} \mathrm{C}\right): \delta 160.1(\mathrm{C}-\mathrm{N}), 160.0(\mathrm{C}-\mathrm{O}), 140.8,137.6$, 134.2, 129.7, 129.0, 127.6, 127.5, 127.2, 123.2, 123.1, 118.5, 39.7 (br s, $\left.\mathrm{NCH}_{3}\right), 27.3\left(\mathrm{CCH}_{3}\right), 17.8$ $\left(\mathrm{CCH}_{3}\right),-3.8\left(\mathrm{SiMe}_{2}\right)$. Anal. calcd. for $\mathrm{C}_{39} \mathrm{H}_{50} \mathrm{Cl}_{2} \mathrm{~N}_{2} \mathrm{O}_{2} \mathrm{Si}_{2} \mathrm{Zr}: \mathrm{C}, 58.76 ; \mathrm{H}, 6.32 ; \mathrm{N}, 3.51$. Found: C, 59.02; H, 6.99; N, 3.78.

Crystal Structure Determination of 2-Zr and 3. Crystals of 2-Zr and 3 suitable for X-ray diffraction analysis were obtained by recrystallization of purified products (see the Experimental section). Diffraction data were collected at $150 \mathrm{~K}$ using a Bruker APEX CCD diffractometer with graphite-monochromatized MoK $\alpha$ radiation $(\lambda=0.71073 \AA)$. A combination of $\omega$ and $\phi$ scans was carried out to obtain at least a unique data set. The crystal structures were solved by direct methods, remaining atoms were located from difference Fourier synthesis followed by full-matrix leastsquares refinement based on F2 (programs SIR97 and SHELXL-97). ${ }^{22}$ For 3, the contributions of the disordered solvents to the calculated structure factors were estimated following the BYPASS algorithm, ${ }^{23}$ implemented as the SQUEEZE option in PLATON. ${ }^{24}$ New data sets, free of solvent contribution, were then used in the final refinement. All non-hydrogen atoms were refined with anisotropic atomic displacement parameters. $\mathrm{H}$ atoms were finally included in their calculated positions. Crystal data and details of data collection and structure refinement for the different compounds are summarized in Table S1. Main crystallographic data (excluding structure factors) are available as Supporting Information, as cif files.

Computational Details. The calculations were performed using the Gaussian $09^{25}$ program employing B3PW91 ${ }^{26}$ functional, and using a standard double- $\xi$ polarized basis set, namely the LANL2DZ set, augmented with a single polarization $f$ function on titanium and zirconium (1.506 and 0.875, respectively). The solvent effects, in our case for toluene, were taken into account during all the calculations by means of the SDM model. ${ }^{27}$ All stationary points were fully characterized via analytical frequency calculations as either true minima (all positive eigenvalues) or transition states (one imaginary eigenvalue). The IRC procedure was used to confirm the nature of each transition state connecting two minima. ${ }^{28}$ Zero-point vibrational energy 
corrections (ZPVE) were estimated by a frequency calculation at the same level of theory, to be considered for the calculation of the total energy values. Pictures of orbitals were generated using the program MOLEKEL 5.4.0.8. ${ }^{29}$

Typical procedure for propylene polymerization. A $300 \mathrm{~mL}$ high-pressure glass reactor was charged with $80 \mathrm{~mL}$ of freshly distilled toluene under argon flash. Mechanical stirring (Pelton turbine, $1000 \mathrm{rpm}$ ) was started, the reactor was then purged with propylene and loaded with a solution of MAO or TIBAL (when used) at atmospheric pressure, and then kept at the desired temperature by circulating water in the double wall. A solution of $\left[\mathrm{Ph}_{3} \mathrm{C}\right]^{+}\left[\mathrm{B}\left(\mathrm{C}_{6} \mathrm{~F}_{5}\right)_{4}\right]^{-}$(when relevant) in $2 \mathrm{~mL}$ of toluene was injected in by syringe, followed by injection a solution of the precatalyst in $2 \mathrm{~mL}$ of toluene. The gas pressure in the reactor was maintained immediately and kept constant with a back regulator throughout the experiment. After a given time period, the reactor was depressurized and the reaction was quenched by adding ca. $5 \mathrm{~mL}$ of a $10 \%$ solution of $\mathrm{HCl}$ in methanol. Since oligomers of propylene were formed, the toluene solution was washed twice with a water/ $\mathrm{HCl}$ solution and, then, with water. An aliquot of the toluene solution $(1 \mathrm{~mL})$ was then analyzed by GLC to probe the presence of light oligomers. The rest was evaporated and dried under vacuum to afford oily materials.

Typical procedure for styrene polymerization. In a typical experiment (Table S3, entry 1), a $50 \mathrm{~mL}$ Schlenk flask equipped with a magnetic stirring bar was charged subsequently with the desired amount of the group 4 metal complex, toluene, the desired co-activator, and styrene. The mixture was stirred vigorously at the required temperature for the desired time, during which an increase of viscosity was observed. The reaction mixture was quenched by the addition of $\mathrm{MeOH}$ and then poured into a large amount of $\mathrm{MeOH}$ to precipitate the polymer, which was dried under vacuum at $60{ }^{\circ} \mathrm{C}$ and weighted.

Acknowledgments. Total S.A. (grants to L.A. and E.K.) for funding. 
Supporting Information available. Crystallographic data for $\mathbf{2 - Z \mathbf { r }}$ and $\mathbf{3}$ as CIF files; NMR spectra of complexes $\mathbf{2}-\mathbf{T i}, \mathbf{2}-\mathbf{Z r}, \mathbf{3}$ and of some polymers.

\section{Notes and References}

(a) Resconi, L.; Fritze, C. Polypropylene Handbook ; Pasquini, N. Ed.; Hanser Publishers, Munich, 2005, pp 107-147. (b) Fink, G.; Brintzinger, H. H. Metal-Catalysis in Industrial Organic Processes; Chiusoli, G. P.; Maitlis, P. M., Eds.; Royal Society of Chemistry, Colchester, 2006, pp 218-254.

(a) Coates, G. W.; Waymouth, R. M. Science 1995, 267, 217. (b) Wagener, K. B. Science 1995, 267, 191. (b) Hauptman, E.; Waymouth, R. M. J. Am. Chem. Soc. 1995, 117, 11586. (c) Maciejewski Petoff, J. L.; Bruce, M. D.; Waymouth, R. M.; Masood, A.; Lal, T. K.; Behred, S. J. Organometallics 1997, 16, 5909. (d) Lin, S.; Hauptman, E.; Lal, T. K.; Waymouth, R.; Quan, R. W.; Ernst, A. B. J. Mol. Cat. A: Chem. 1998, 136, 23. (e) Carlson, E. D.; Krejchi, M. T.; Shah, C. D.; Terakawa, T. Waymouth, R. M.; Fuller, G. G. Macromolecules 1998, 31, 5343. (f) Hu, Y.; Krejchi, M. T.; Shah, C. D.; Myers, C. L.; Waymouth, R. M. Macromolecules 1998, 31, 6908. (e) Carlson, E. D.; Krejchi, M. T.; Shah, C. D.; Terakawa, T. Waymouth, R. M.; Fuller, G. G. Macromolecules 1998, 31, 5343. (g) Witte, P.; Lal, T. K.; Waymouth, R. M. Organometallics 1999, 18, 4147. (h) Nele, M.; Collins, S.; Dias, M. L.; Pinto, J. C.; Lin, S.; Waymouth, R. M. Macromolecules 2000, 33, 7249. (i) Lin, S.; Tagge, C. D.; Waymouth, R. M.; Nele, M.; Collins, S.; Pinto, J. C. J. Am. Chem. Soc. 2000, 122, 11275. (j) Lin, S.; Waymouth, R. M. Acc. Chem. Res. 2002, 35, 765.

(a) Pietsch, M. A.; Rappe, A. K. J. Am. Chem. Soc. 1996, 118, 10908. (b) Mansel, S.; Perez, E.; Benavente, R.; Perena, J. M.; Bello, A.; Roll, W.; Kirsten, R.; Beck, S.; Brintzinger, H.-H. Macromol. Chem. Phys. 1999, 200, 1292. (c) Knuppel, S.; Faure, J.-L.; Erker, G.; Kehr, G.; Nissinen, M.; Frohlich, R. Organometallics 2000, 19, 1262. (d) Schneider, N.; Schaper, F.; 
Schmidt, K.; Kirsten, R.; Geyer, A.; Brintzinger, H.-H. Organometallics 2000, 19, 3597. (e)

Dreier, T.; Erker, G.; Frohlich, R.; Wibbeling, B. Organometallics 2000, 19, 4095. (f) Maiti, A.; Sierka, M.; Andzelm, J.; Golab, J.; Sauer, J. J. Phys. Chem. A 2000, 104, 10932.

(a) Busico, V.; Cipullo, R.; Segre, A.; Talarico, G.; Vacatello, M.; Axel Castelli, V. Macromolecules 2001, 34, 8412. (b) Busico, V.; Cipullo, R.; Kretschmer, W.; Talarico, G.; Vacatello, M.; Van Axel Castelli, V. Macromol. Symp. 2002, 189, 127. (c) Busico, V.; Cipullo, R.; Kretschmer, W. P.; Talarico, G.; Vacatello, M.; Van Axel Castelli, V. Angew. Chem., Int. Ed. 2002, 41, 505. (d) Busico, V.; Van Axel Castelli, V.; Aprea, P.; Cipullo, R.; Segre, A.; Talarico, G.; Vacatello, M. J. Am. Chem. Soc. 2003, 125, 5451. Lyakin, O. Y.; Bryliakov, K. P.; Semikolenova, N. V.; Lebedev, A; Y.; Voskoboynikov, A. Z.; Zakharov, V. A.; Talsi, E. P. Organometallics 2007, 26, 1536-1540.

(a) Agapie, T.; Henling, L. M.; DiPasquale, A. G.; Rheingold, A. L.; Bercaw, J. E. Organometallics 2008, 27, 6245. (b) Agapie, T.; Day, M. W.; Bercaw, J. E. Organometallics 2008, 27, 6123. (c) Winston, M. S.; Bercaw, J. E. Organometallics 2010, 29, 6408-6416. (d) Tonks, I. A.; Tofan, D.; Weintrob, E. C.; Agapie, T.; Bercaw, J. E. Chem. Commun. 2012, 48, 6657-6659. (d) Lenton, T. N.; Vander Velde, D. G.; Bercaw, J. E. Organometallics 2012, 31, 7492-7499. (e) Tonks, I. A.; Meier, J. C.; Bercaw, J. E. Organometallics 2013, 32, 3451-3457. (f) Despagnet-Ayoub, E.; Henling, L. M.; Labinger, J. A.; Bercaw, J. E. Dalton Trans. 2013, 42, 15544-15547. (g) Klet, R. C.; Theriault, C. N.; Klosin, J.; Labinger, J. A.; Bercaw, J. E. Macromolecules 2014, 47, 3317-3324. (h) Despagnet-Ayoub, E.; Takase, M. K.; Henling, L. M.; Labinger, J. A.; Bercaw, J. E. Organometallics 2015, 34, 4707-4716. Kirillov, E.; Roisnel, T.; Razavi, A.; Carpentier, J.-F. Organometallics 2009, 28, 5036-5051. $10762-10763$. 
The neutral Y(III) complex is an isoelectronic model for a putative $\mathrm{Zr}$ (IV) cationic species of the type $\left[\left(\mathrm{C}_{5} \mathrm{Me}_{5}\right)_{2} \mathrm{ZrCH}_{2} \mathrm{CH}_{2} \mathrm{CH}(\mathrm{Me})_{2}\right]^{+}$. The corresponding insertion barriers for the latter species (11-12 kcal $\cdot \mathrm{mol}^{-1}$ ) have been estimated by DFT computations, see: Castro, L.; Kirillov, E.; Miserque, O.; Welle, A.; Haspeslagh, L.; Carpentier, J.-F.; Maron, L. ACS Catalysis 2015, 5, 416-425.

Activation of group 4 metal benzyl complexes with $\mathrm{B}\left(\mathrm{C}_{6} \mathrm{~F}_{5}\right)_{3}$ is typically used for preparation of the corresponding alkyl cations. (a) Pellecchia, C.; Grassi, A.; Immirzi, A. J. Am. Chem. Soc. 1993, 115, 1160-1162. (b) Pellecchia, C.; Immirzi, A.; Grassi, A.; Zambelli, A. Organometallics 1993, 12, 4473-4478. (c) Thorn, M. G.; Etheridge, Z. C.; Fanwick, P. E.; Rothwell, I. P. Organometallics 1998, 17, 3636-3638. (d) Thorn, M. G.; Etheridge, Z. C.; Fanwick, P. E.; Rothwell, I. P. J. Organomet. Chem. 1999, 591, 148-162. (e) Gountchev, T. I.; Don Tilley, T. Inorg. Chim. Acta 2003, 345, 81-88. (f) Shafir, A.; Arnold, J. Organometallics 2003, 22, 567-575. (g) Shimo, I.; Okumura, T.; Goto, K.; Kawashima, T. J. Organomet. Chem. 2007, 692, 2115-2119. (h) Noor, A.; Kretschmer, W. P.; Glatz, G.; Meetsma, A.; Kempe, R. Eur. J. Inorg. Chem. 2008, 5088-5098. (i) Gowda, R.; Chen, E. Y.X. Dalton Trans. 2008, 42, 9263-9275.

11 Experiments using molecular activators $\left[\mathrm{Ph}_{3} \mathrm{C}\right]^{+}\left[\mathrm{B}\left(\mathrm{C}_{6} \mathrm{~F}_{5}\right)_{4}\right]^{-}$and $\left[\mathrm{PhNMe}_{2} \mathrm{H}\right]^{+}\left[\mathrm{B}\left(\mathrm{C}_{6} \mathrm{~F}_{5}\right)_{4}\right]^{-}$in the reactions with $\mathbf{2}-\mathbf{T i}$ and $\mathbf{2 - Z \mathbf { Z }}$, monitored by NMR spectroscopy in toluene- $d_{8}$ in the temperature range of $-70-+25^{\circ} \mathrm{C}$, resulted in intractable mixtures of unidentified compounds.

12 Typically, the corresponding $|\Delta \delta(m, p-\mathrm{F})|$ values for ISIPs are greater than $3.5 \mathrm{ppm}$, while those for OSIPs are smaller than 3.0 ppm; see: Ciancaleoni, G.; Fraldi, N.; Budzelaar, P. H. M.; Busico, V.; Macchioni, A. Dalton Trans. 2009, 8824-8827 and references cited therein. Note that another interpretation of these data can be envisioned: the presence of the two singlet resonances of equal intensity in the ${ }^{29} \mathrm{Si}\left\{{ }^{1} \mathrm{H}\right\}$ NMR spectrum of 2-Ti (Fig. S6) may reflect the coexistence of two $C_{\mathrm{s}}$-symmetric species in equal amounts. This assumption is consistent with the average $C_{\mathrm{s}}$-symmetry pattern of the major species observed in the 
corresponding ${ }^{1} \mathrm{H}$ NMR spectra of 2-Ti registered at the same temperature (223 and $243 \mathrm{~K}$, see Fig. S4).

The following atom numbering of the naphtholate unit is used:<smiles>Cc1c(O)c([123I])cc2ccccc12</smiles>

The fact that the ratio between the two isomers is thermodynamically controlled was confirmed by the following experiment: an NMR tube with the desired sample was re-heated at room temperature over $1 \mathrm{~h}$ and ${ }^{1} \mathrm{H}$ NMR spectroscopy was recorded again at $-50{ }^{\circ} \mathrm{C}$. The same ratio between the two isomers was observed, whatever the cooling rate.

$$
\frac{N_{1}}{N_{2}}=\frac{g_{1}}{g_{2}} e^{-\frac{\Delta E}{R T}},
$$

where $\frac{N_{1}}{N_{2}}$ is the molar isomeric ratio, $g_{1}=g_{2}=$ degeneracy. (a) Goodman, J. M.; Kirby, P. D.; Hausted, L. O. Tetrahedron Lett. 2000, 41, 9879. (b) McQuarrie, D. A.; Simon, J. D. Molecular Thermodynamics; University Science Books: Sausalito, California, 1999. and $\mathbf{2}$-Ti- $\boldsymbol{C}_{\mathbf{s}}$-decoord(2) is evidenced from their lower energies $(-0.1249,-0.1314$ and -0.1367 a.u., respectively) as compared to those of the LUMOs in the zirconium based

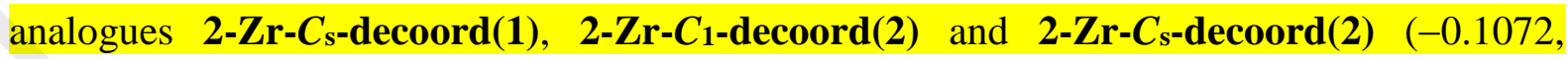
-0.1099 and -0.1179 a.u., respectively). Such dissimilarity between titanium- and zirconium-based systems may be a result of a smaller effective ionic radius of the former ion (for 4-coordinate metal centers: $\mathrm{Ti}^{4+}, 0.42 \AA$; $\mathrm{Zr}^{4+}, 0.59 \AA$ A), see: Shannon, R. D. Acta Crystallogr., Sect. A 1976, A32, 751-767. 
Warren, T. H.; Erker, G.; Frohlich, R.; Wibbeling, B. Organometallics, 2000, 19, 127-134.

The regioregular microstructure of this polymers is confirmed by the absence of signals from the $\mathrm{CH}_{2}-\mathrm{CH}_{2}$ sequences in the low-field ${ }^{13} \mathrm{C}\left\{{ }^{1} \mathrm{H}\right\}$ NMR spectrum, which would come out in the region of $\delta$ 38-40 ppm, see: Rodrigues, A.-S.; Kirillov, E.; Lehmann, C. W.; Roisnel, T.; Vuillemin, B.; Razavi, A.; Carpentier, J.-F. Chem. Eur. J. 2007, 13, 5548-5565. Feil, F.; Harder, S. Macromolecules 2003, 36, 3446-3448.

(a) Sheldrick, G. M. SHELXS-97, Program for the Determination of Crystal Structures, University of Goettingen (Germany), 1997. (b) Sheldrick, G. M. SHELXL-97, Program for the Refinement of Crystal Structures, University of Goettingen (Germany), 1997. Sluis, P. V. D.; Spek, A. L. Acta Cryst. 1990, A46, 194-201. 5648.

Marenich, A. V.; Cramer, C. J.; Truhlar, D. G. J. Phys. Chem. B, 2009, 113, 6378.

Gonzales, C.; Schlegel, H. B. J. Chem. Phys. 1989, 90, 2154.

Varetto, U. MOLEKEL 5.4.0.8; Swiss National Supercomputing Centre (CSCS): Lugano, Switzerland, 2009; http://www.cscs.ch. 


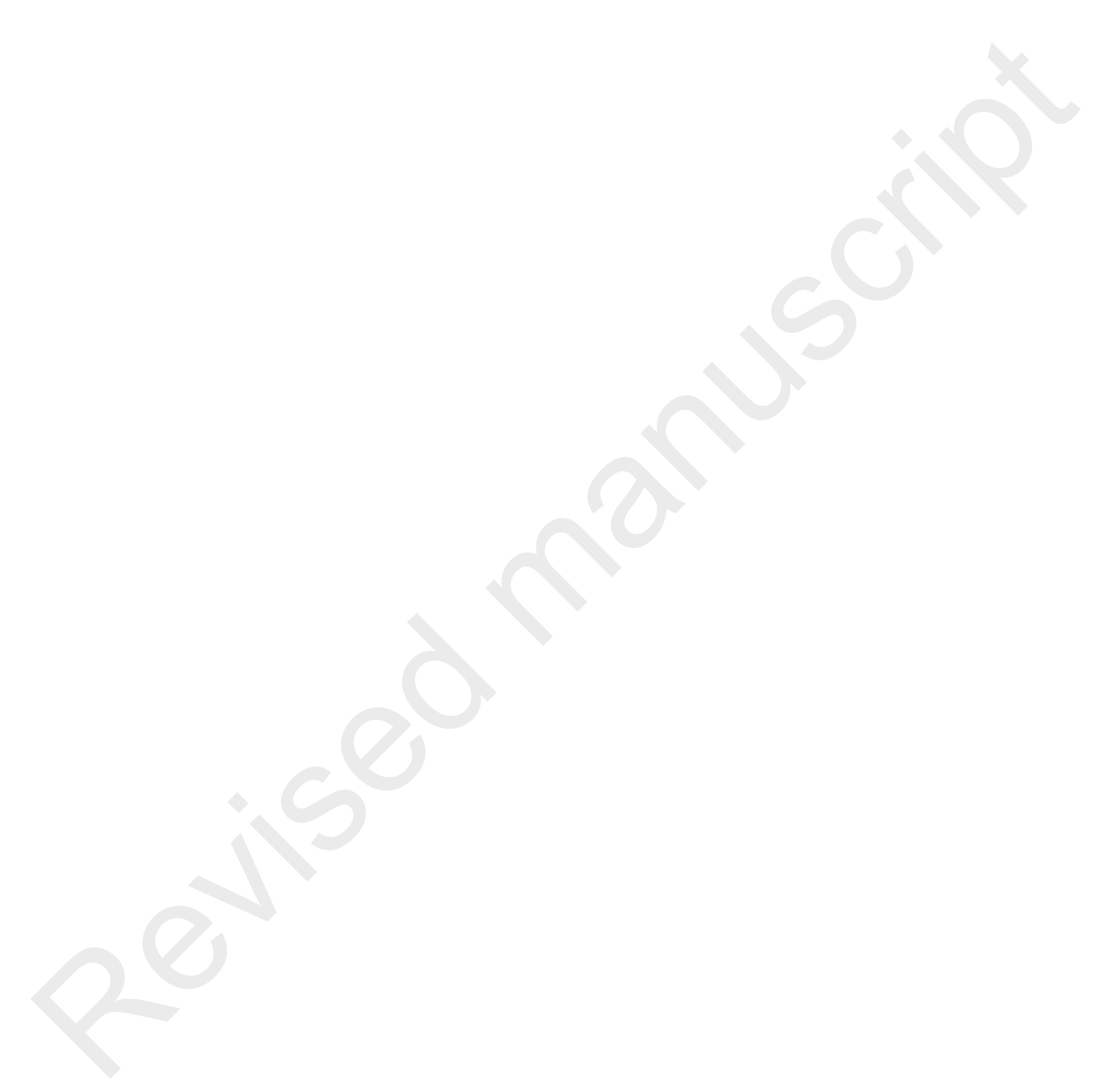

